Review

\title{
Environmental challenges impeding the composting of biodegradable municipal solid waste: A critical review
}

\author{
Yunmei Wei ${ }^{\mathrm{a}, *}$, Jingyuan $\mathrm{Li}^{\mathrm{a}}$, Dezhi Shi ${ }^{\mathrm{a}}$, Guotao Liu ${ }^{\mathrm{a}}$, Youcai Zhao ${ }^{\mathrm{b}}$, Takayuki Shimaoka ${ }^{\mathrm{c}}$
}

\author{
a Key Laboratory of Three Gorges Reservoir Region's Eco-Environment, Ministry of Education, Chongqing University, Chongqing, 400 045, PR China \\ b State Key Laboratory of Pollution Control and Resource Reuse, Tongji University, Shanghai, 200092, PR China \\ c Department of Urban and Environmental Engineering, Graduate School of Engineering, Kyushu University, Fukuoka, 8190395, Japan
}

\section{A R T I C L E I N F O}

\section{Article history:}

Received 16 August 2016

Received in revised form

29 December 2016

Accepted 29 January 2017

Available online 14 February 2017

\section{Keywords:}

Biodegradable municipal solid waste

Recycling

Composting

Odors

Bioaerosols

Heavy metals

\begin{abstract}
A B S T R A C T
Biodegradable material, primarily composed of food waste, accounts for $40-70 \mathrm{wt} \%$ of municipal solid waste (MSW) in developing countries. Therefore, to establish a sustainable waste management system, it is essential to separate and recycle biodegradable organic material from the municipal waste stream. Of all the recycling methods, composting is recommended due to its environmental and economic benefits. However, compared with readily recyclable materials (e.g., paper, metals, etc.), recycling/composting biodegradable MSW presents a great challenge to furthering the promotion of waste recycling.

This review provides a systematic analysis of organic waste sorting and recycling/composting practices in several countries: the UK, US, Japan, and China. Compared to the great efforts that have been made in developed countries for the promotion of waste composting, much less has been achieved in developing countries. For example, the MSW composting rate in China decreased from $10 \%$ to less than $2 \%$ in the past 15 years, and similar trends may exist in other developing countries. Therefore, it is essential to identify the barriers that impede waste composting and predict developing trends. This article emphasizes environmental challenges (i.e., odor, bioaerosols, and heavy metals), focusing on their generation and control strategies, in an effort to identify barriers hindering MSW composting. Successful practices in several European countries suggest that source-separated composting presents many advantages over mechanical-separated composting. This may partially be ascribed to the fact that source separation of organic waste can prevent contact with heavy metal-bearing items, resulting in the production of highquality compost. Mixed collection MSW normally contains significantly higher concentrations of heavy metals, which could affect the marketing of composting products. Moreover, source separation of organic waste can minimize waste pretreatment operations, leading to lower bioaerosol and malodor generation during composting. Implementing source separation of MSW in more countries would increase the amount of organic waste available for composting. In addition, attention should focus on secondary pollutant production for proper composting management. Finally, setting standards for end product quality control is highly recommended for controlling both marketing and environmental risks.
\end{abstract}

(c) 2017 Elsevier B.V. All rights reserved.

Contents

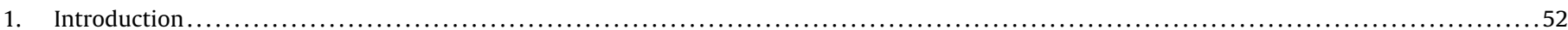

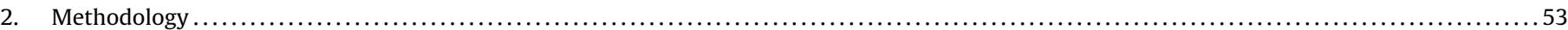

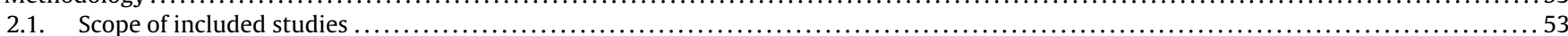

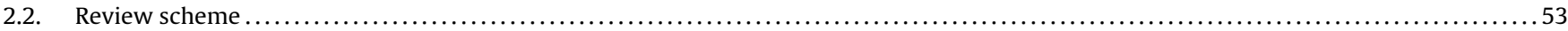

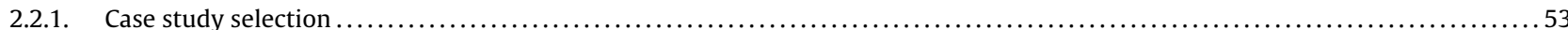

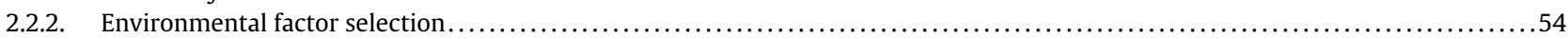

\footnotetext{
* Corresponding author.

E-mail addresses: wym_1982@cqu.edu.cn, creansr@126.com (Y.Wei).
} 


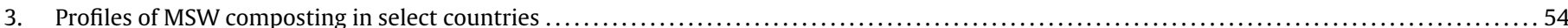

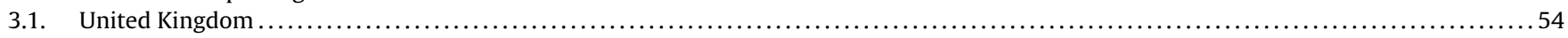

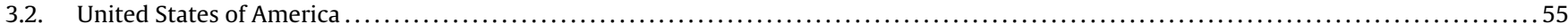

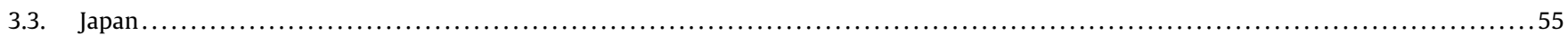

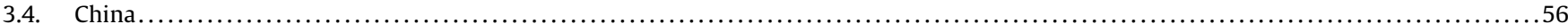

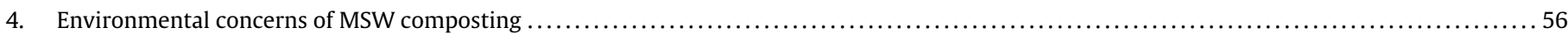

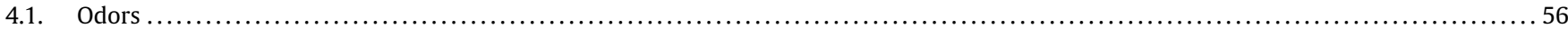

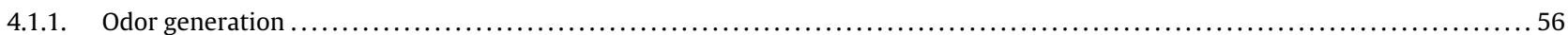

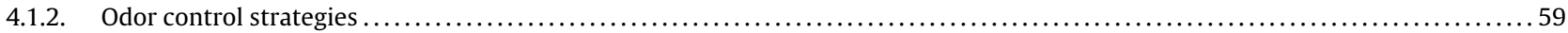

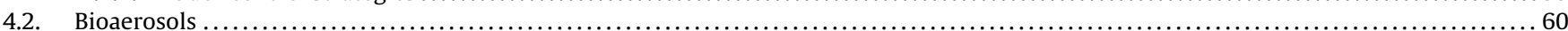

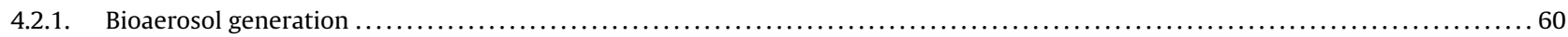

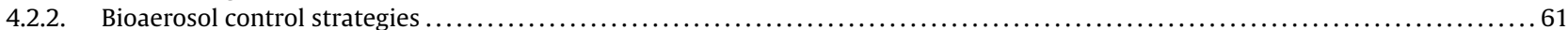

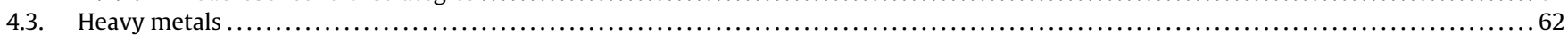

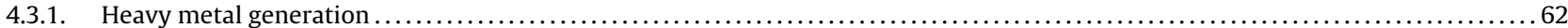

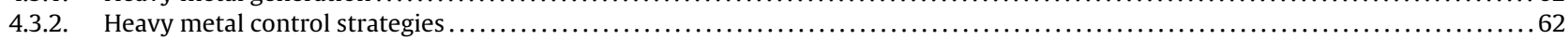

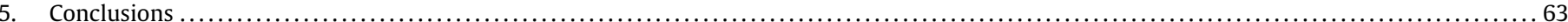

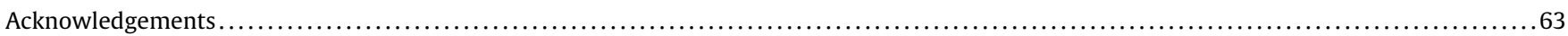

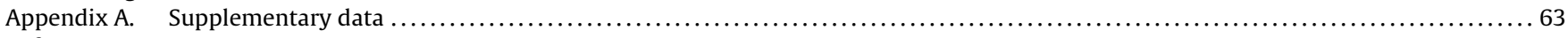

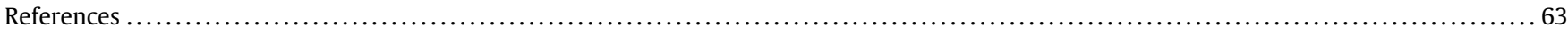

\section{Introduction}

There has been increasing attention on improving the management of the organic fraction of municipal solid waste (OFMSW). Biodegradable material, especially food waste, normally accounts for over $50 \mathrm{wt} \%$ of the municipal/residential waste stream in less developed countries (Alexis and James, 2009; Tai et al., 2011; Thi et al., 2015). Thus, diversion of organic material from the waste stream, by either source separation or centralized mechanical separation, is a prerequisite for further treatment by more environmentally friendly methods, such as composting. Composting is a method of waste recycling based on the biological degradation of organic matter under aerobic conditions, producing stabilized and sanitized compost products. Diverting municipal solid waste (MSW) organic material from landfills by composting has many environmental benefits, such as reducing greenhouse gas emissions (USEPA, 2015), decreasing leachate quantities once discarded in landfills (Adhikari et al., 2009), and increasing the calorific value of feedstock to generate more energy in case of incineration (Zhou et al., 2014). The United States Environmental Protection Agency (USEPA) calculated the improvements in greenhouse gas production associated with the recovery of organic matter from MSW by composting. According to the results, over 22 million tons of food waste and yard trimmings were composted in the USA in 2013, providing an annual reduction of more than 2.74 million tons of carbon dioxide equivalent emissions, comparable to removing the emissions from over 528,000 passenger vehicles in 1 year (USEPA, 2013). From a lifecycle perspective (Laurent et al., 2014; Eriksson et al., 2015), other benefits, such as the production of compost that can potentially be used as organic fertilizer or for soil amendments, can also be derived from the diversion of organic material from landfill disposal or incineration. Adding compost to soil provides nutrients for plant growth, improves the soil structure, increases the water retention capacity, and reduces the reliance on fossil-fuel-based fertilizers (Jordāo et al., 2006; Chen et al., 2015; Hernández et al., 2015). Centralized composting has been adopted in many regions worldwide to divert organic waste (e.g., green waste, kitchen waste, etc.) from landfills and incinerators (Eurostat, 2015). Removing green waste, such as yard trimmings, sweeping waste, and garden waste from the municipal waste stream has long been implemented in North America (Levis et al., 2010; USEPA, 2013) and some European countries, including the UK, Germany, and Spain (Slater and Frederickson, 2001). However, food waste diversion lags far behind green waste diversion. Regardless, great efforts to recycle food waste for composting have been undertaken, especially in several
European countries. The Landfill Directive (1999/31/EC) and Waste Framework Directive (2008/98/EC) require European Union (EU) member states to reduce the amount of biodegradable municipal waste sent to landfills and recycle organic fractions using more environmentally benign options. In the past two decades, EU member states have adopted a series of measures to comply with such targets. For example, more stringent landfill tax policies have been adopted by more than 20 countries to minimize the biodegradable municipal waste sent to landfills (Fischer et al., 2012). In addition, separate collection of organic waste has been implemented in half of the EU member states. Specifically, door-to-door food waste collection systems have been established in 13 member states, and an additional two member states operate door-to-door collection systems for garden waste alone. Meanwhile, $12 \mathrm{EU}$ member states do not collect organic waste separately in their primary collection system (Seyring et al., 2015). Finally, setting standards for the endproducts of composting is a key element in promoting sustainable organic material recycling. Such criteria include national compost quality assurance systems and Europe-wide quality assurance for compost (i.e., the "Standardization \& Quality Assurance" directive developed by the European Compost Network) (ECN, 2014).

Various environmental issues may arise during the composting process, including the formation of malodorous or toxic gases (Komilis et al., 2004; Mao et al., 2006; Maulini-Duran et al., 2014a), bioaerosols (Albrecht et al., 2007; Sykes et al., 2011; Wéry, 2014), and dust (Byeon et al., 2008; Sykes et al., 2011), resulting in occupational health risks or disturbance to nearby residents (Sykes et al., 2007; van Kampen et al., 2012; Pearson et al., 2015). This is especially pertinent to composting plants operated in open spaces. Moreover, waste-derived compost may elevate heavy metal concentrations in soil and food products cultivated in soil amended with MSW compost (Smith, 2009). Composting, when managed appropriately, is a sustainable waste management option that has various benefits, including reducing greenhouse gas production and improving soil quality when used as a soil amendment. However, when improperly managed and performed, composting may lead to the above-mentioned environmental issues.

This article provides a critical review of MSW composting practices in developed and less-developed countries, the environmental and ecological impacts of MSW composting and compost due to chemical or biological contaminants, their control strategies, and compost quality control measures. Such information may be particularly useful in assisting less developed countries seeking to upgrade their sustainable waste management strategies. 

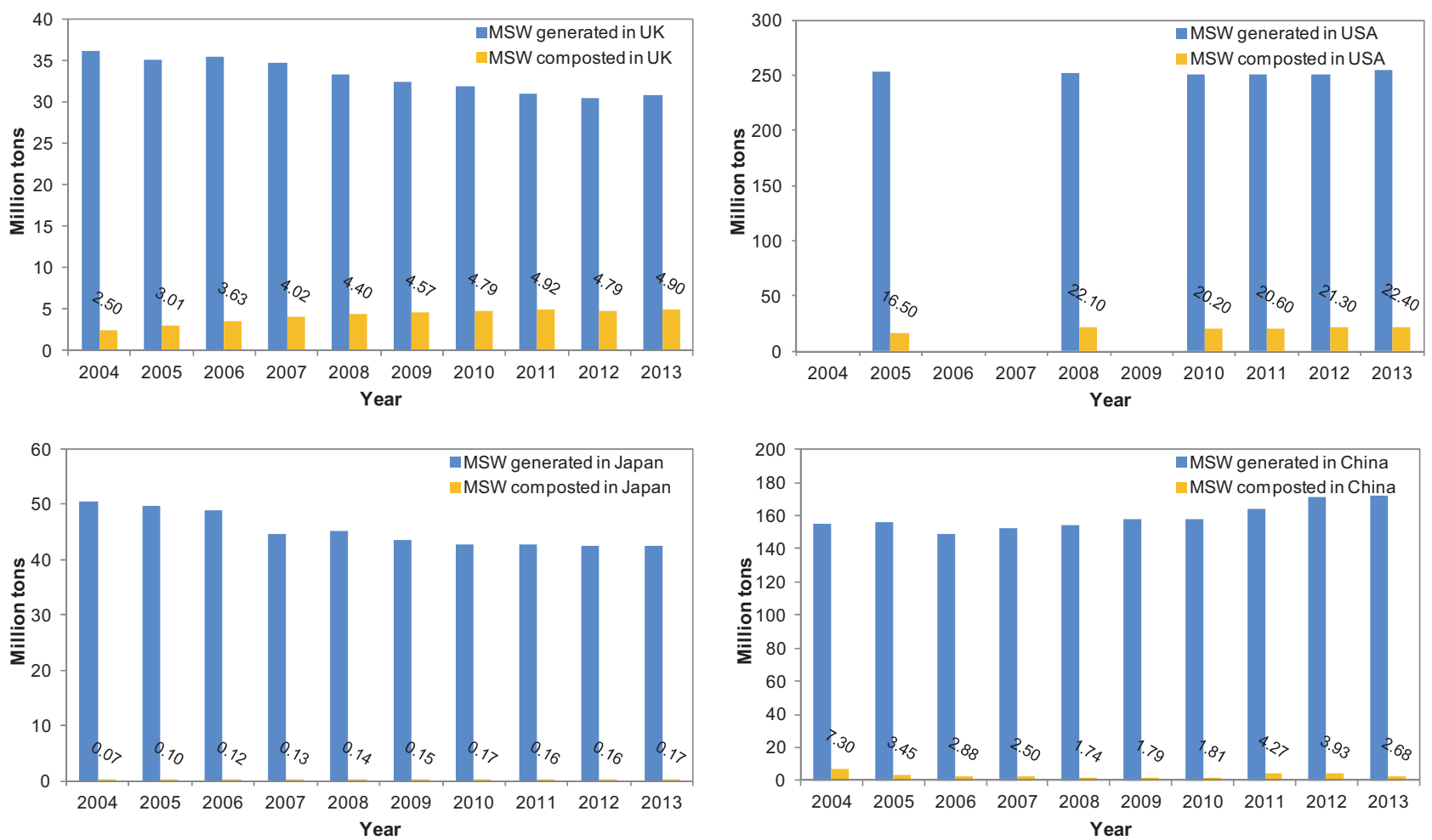

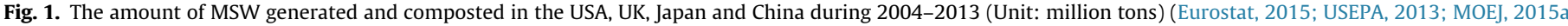
National Bureau of Statistics of China, 2015).

\section{Methodology}

\subsection{Scope of included studies}

This review mainly focuses on the composting of MSW. The definition of MSW varies among countries, depending on the local waste management system. MSW consists largely of waste generated by households, and similar waste from sources such as municipal parks and gardens/yards, offices, public institutions, and businesses. Therefore, any legislation and activities related to composting waste within the scope of this definition of MSW are included in this article. In addition, although composting is commonly adopted for the treatment of solid residues from anaerobic digestion, it is more typically regarded as an end-of-pipe solution rather than a direct waste management method for MSW; therefore, studies solely focusing on composting solid residues of other intermediate waste treatment processes are not within the scope of this review.

This review frequently refers to 'recycling', and it is necessary to distinguish 'recycling' from 'composting' to clarify the scope. Recycling refers to any recovery operation by which waste materials are reprocessed into products, materials, or substances, whether for the original purpose or other purposes (Waste Framework Directive 2008/98/EC). Organic waste recycling includes composting, anaerobic digestion, animal feed production, and other reprocessing operations of organic materials, but does not include energy recovery or reprocessing into materials to be used as fuels or for backfilling operations. Based on these definitions, MSW composting can be viewed as a waste recycling method.

\subsection{Review scheme}

\subsubsection{Case study selection}

The methodology followed to achieve the goals of this review includes a case study analysis of select countries and a thorough analysis of the environmental challenges that may impede MSW composting. The UK, USA, Japan, and China were selected for the case study given their geographical, socio-economic, waste composition, and waste management profiles. The UK was selected as a representative country of EU nations. In the EU, member states have enacted various measures to reduce the amount of biodegradable municipal waste sent to landfills and recycle these organic fractions using more environmentally benign methods, which are enforced by the Landfill Directive (1999/31/EC) and Waste Framework Directive (2008/98/EC) (please refer to Section 1 for details of these measures) (ECN, 2014; Fischer et al., 2012; Seyring et al., 2015). The USA and Japan were selected as examples of countries outside the $\mathrm{EU}$, where recycling of organic waste, especially food waste from households, has only been implemented in a few states or cities. In these countries, the majority of organic waste is treated similarly to inert (non-biodegradable) waste, and is not strictly regulated for a specific recycling purpose (USEPA, 2013; Platt et al., 2014; MOEJ, 2015b). For example, in Japan, MSW is generally classified into recyclable materials (i.e., metallic items, glass, plastics, newspapers, and cardboards), and the remnant proportion, which accounts for over $75 \mathrm{wt} \%$ of all MSW, is incinerated for mass reduction and energy recovery purposes. In addition, Japan was selected for this review due to its markedly different waste composition profile from those of the EU and USA (see Fig. 1). China has witnessed rapid economic development over the past few decades, during which period the waste generation rate dramatically increased, reaching 178.60 million tons by 2014 (National Bureau of Statistics of China, 2015). MSW in China comprises a high percentage of food waste (see Fig. 1), which is typical of MSW in developing countries (Alexis and James, 2009). The Chinese government is currently pursuing a sustainable and suitable waste management strategy (World Bank, 2005). Thus, China was selected as representative of developing countries. In the case study, composting practices are examined in terms of the total amount of MSW composted, developing trends 
of composting are examined within the context of waste management methods, and key policies that affect MSW composting are discussed within the context of each nation.

\subsubsection{Environmental factor selection}

Although composting is generally regarded as an environmentally benign waste management option, its potential occupational and public (e.g., composting plant workers, nearby residents, or consumers of food products cultivated in soils using MSW compost) health risks should not be neglected. In general, the major environmental concerns associated with MSW composting include malodor, bioaerosol, dust, noise, and leachate generation during various composting operations, as well as their release to the surrounding environment beyond the composting facilities (Eitzer, 1995; Bünger et al., 2007; Sykes et al., 2007), together with potential exposure to heavy metals, organic pollutants, and pathogenic agents in the case of compost application to soil (Hargreaves et al., 2008). Of these concerns, odors, bioaerosols, and heavy metals have been most intensively studied due to their high potential risks; therefore, they are the focus of this review. An additional explanation of their inclusion in this review is provided below.

Among the environmental factors associated with MSW composting, odor has attracted great attention due to its substantial impact on environmental health and quality of life. In 2005, the Taiwan Environmental Protection Administration legislated mandatory recycling and composting of household food waste. However, malodors from food waste composting plants present another problem. In 2004 and 2005, four food waste composting plants located in north and central Taiwan were forced to shut down due to protests from nearby residents. Malodors are probably the most demanding challenge for emerging environmental policy in Taiwan (Tsai et al., 2008).

Bioaerosols from composting plants have been observed to penetrate deep into the lungs due to their small particle size (Byeon et al., 2008; O'Connor et al., 2015). A particle size distribution analysis of airborne bioaerosols released from a green waste composting site on operating days revealed that bioaerosols were predominantly $0.5-3 \mu \mathrm{m}$ wide (average $\sim 2 \mu \mathrm{m}$ ) (O'Connor et al., 2015). Their small size implies a high possibility of inhalation by humans, which can cause respiratory or gastro-intestinal symptoms (Douwes et al., 2003; Bünger et al., 2007; Walser et al., 2015). Bioaerosols have become a major environmental concern at composting plants. In the past decades, an increasing number of studies have aimed to determine source emissions, collect dose-response data, and create dispersion models for bioaerosols, which are essential for developing reliable risk assessments, managing potential risks, and thus facilitating OFMSW diversion and composting.

As mentioned above, using compost as a soil amendment significantly reduces soil erosion, improves the soil structure and fertility, increases the water retention capacity, and restores soil nutrient, macroelement, and microelement contents. However, compost products derived from MSW may contain various pollutants that can pose environmental or health risks, including heavy metals, transition metals, salts, organic contaminants, and pathogenic organisms, as well as physical contaminants, such as stones, glass, or other inert particles (Domingo and Nadal, 2009). Thus, adding MSW-derived compost to soil has attracted concern from environmentalists focusing on the potential adverse effects on the environment. Smith (2009) assessed the risk of heavy metals from MSW-derived compost applied to land and found that the MSW-derived compost contained heavy metal concentrations greater than the background soil levels. Therefore, applying MSWderived compost to soils could increase metal concentrations at application sites, resulting in an increased uptake of labile ele- ments, such as zinc ( $\mathrm{Zn})$ and copper $(\mathrm{Cu})$, by crops (Hargreaves et al., 2008). These results underline the importance of controlling heavy metals in MSW-derived compost to minimize such risks.

\section{Profiles of MSW composting in select countries}

\subsection{United Kingdom}

The implementation of the EU's Landfill Directive (EC/31/99) and revised Waste Framework Directive (2008/98/EC) has resulted in the enforcement of mandatory targets for member nations to minimize the quantity of biodegradable waste entering landfills, stimulating a rapid growth in industrial composting. According to Eurostat (Eurostat, 2015), the percentage of MSW composted in EU nations increased from $8 \%$ to $15 \%$ between 1999 and 2013. To meet the mandatory targets of diverting biodegradable waste from landfills, the UK initially employed the Landfill Allowance Trading Scheme, which was launched in England, Wales, and Northern Ireland in 2004 and in Scotland in 2005. This was followed by the introduction of an escalated landfill tax policy. Owning to the rapid increase in the landfill tax in the UK, from $7 \mathrm{GBP} /$ ton to $84 \mathrm{GBP} /$ ton of active waste in 1996 and 2016, respectively, analysts believe that landfill tax escalation has become the main economic incentive to divert active waste, including biodegradable MSW, from landfills (Edwards et al., 2015).

Driven by the landfill tax policy, there was a rapid increase in household waste composting during the first decade of the millennium. In the fiscal year of 2000/01, only 0.796 million tons of household waste (3\% of the total) was composted in England, while 3.713 million tons of household waste (16\% of the total) was composted in 2009/10 (DEFRA, 2015a). In 2014/15, 4.2 million tons of organic waste, including source-separated food waste and other compostable organics, was recycled (primarily composted) in England, accounting for $19 \%$ of the total household waste collected (DEFRA, 2015a). However, in the same year, the recycling (including reuse and composting) rate of waste from households in England was $44.8 \%$ ( $44.9 \%$ for the UK), lagging behind the Waste Framework Directive target to recycle at least $50 \%$ of household waste by 2020 . This indicates that more efforts are required to meet this target.

At the local authority level (i.e., district level), recycling rates ranged from $18 \%$ to $66 \%$, and only 73 out of 352 local authorities in England achieved a 50\% or higher recycling rate in 2013 (Waite et al., 2015). Districts with high total recycling rates similarly had high green/organic waste recycling rates. For example, the highest household waste recycling rate of 66\% was observed in South Oxfordshire District, with a green/organic waste recycling rate of over 55\%, much higher than the average rate in England of $40 \%$.

These data reveal that a large proportion of food waste is not being recycled. In 2012, 4.67 million tons of food and drink waste were collected by local authorities from homes in the UK, accounting for nearly one-fifth of the waste from households (Bridgwater and Quested, 2012). Of all household food waste, only $12 \%$ was recycled, of which $8 \%$ was collected separately and $4 \%$ was mixed with garden waste (DEFRA, 2015b), resulting in a large proportion of food waste becoming residual waste (i.e., not recycled). Encouragingly, the recycling rate of food waste collected by local UK authorities increased from 88,000 tons in 2007 to 537,000 tons in 2012. Moreover, the amount of food waste collected separately increased over 20 times from 2006 to 2012, from under 15,000 tons to nearly 350,000 tons (Food statistic of pocketbook, 2014). Therefore, recycling of organic waste, especially food waste, will likely continue to increase in the near future to meet the Waste Framework Directive target. Other researchers have drawn similar conclusions (Waite et al., 2015). 


\subsection{United States of America}

Composting has long been used to treat organic waste material in the USA. In 1990, 4.2 million tons of MSW (2.0\% of total MSW) was composted in the USA. Moreover, the amount of waste composted rapidly increased to 20.6 million tons (8.4\% of MSW) by 2005 . The rapid growth of composting in this period was attributable to policies enacted by state and local governments to encourage yard trimmings composting. Most bans on yard trimmings disposal were initiated in the early 1990s by state or local governments; by 2010, 24 states banned sending yard trimmings to landfills (Bell and Platt, 2014). However, the MSW composting industry stagnated in the 10 years after 2005. According to the USEPA, 22.4 million tons of MSW (8.8\% of total MSW) was composted in 2014, similar to the 2005 levels (USEPA, 2013). Landfill tax trends have been shown to be consistent with composting trends. From 1985 to 1995, the landfill tax in the USA increased by $~ 177 \%$, from $\$ 17.75$ per ton to $\$ 49.21$ per ton. However, the landfill tax in 2013 was $\$ 49.99$ per ton, $\sim 1.58 \%$ higher than that in 1995 (USEPA, 2013). Landfill taxes in the USA remained lower than those in the UK and were virtually unchanged for over 15 years, providing little motivation to recycle/compost waste in the USA.

According to USEPA, 37.08 million tons of yard trimmings and 36.83 million tons of food waste were generated in 2013, of which 20.60 million tons and 1.84 million tons of these organic materials were composted, equivalent to recovery rates of $57.7 \%$ and $4.8 \%$, respectively (USEPA, 2013). After MSW recovery via recycling and composting, almost 167 million tons of MSW was discarded in 2013 , of which the largest component was food waste (21\%), suggesting that only a limited proportion of food waste was recovered, while most ended up in landfills or incinerators. Therefore, it can be concluded that the low food waste recycling rate has hindered the increase of the total MSW recycling rate, which has stagnated at $\sim 40 \%$ for more than a decade.

The US federal government recently confirmed the environmental, economic, and social benefits of composting. The name of the annually released document "Municipal Solid Waste Generation, Recycling, and Disposal in the United States: Facts and Figures" was changed to "Advancing Sustainable Materials Management: 2013 Fact Sheet, Assessing Trends in Material Generation, Recycling and Disposal in the United States". This report emphasized the new concept of sustainable material management, which refers to the most productive and sustainable use and reuse of materials over their entire life cycle (USEPA, 2013). A survey conducted by the Institute for Local Self-Reliance analyzed the status of waste composting in the USA (Bell and Platt, 2014). The survey report found that a lack of funding, inadequate regulatory structure, and technical assistance were the main barriers to establishing or expanding composting infrastructure in light of the critical need to increase the organic material processing capacity of the USA. Moreover, the institute found that there has been increasing focus on placing food waste treatment higher on the USEPA's Food Recovery Hierarchy in the USA in recent years. For example, food waste composting increased from 0.68 million tons in 2005 to 1.84 million tons in 2013 (USEPA, 2013). In the USA, diversion of food scraps for recycling/composting has been driven primarily by the establishment of food waste disposal bans (e.g., Connecticut, Massachusetts, and Vermont) or the enactment of organic waste diversion laws (e.g., California) (Bell and Platt, 2014). Moreover, several states (e.g., Massachusetts, Ohio, Oregon, and Washington) have begun to modify their regulations to facilitate source-separated organic material composting, including food waste (Bell and Platt, 2014). Based on the contributions of both federal and state governments, it is hoped that higher waste recycling rates can be achieved, especially if more states begin separating and composting their food waste.

\subsection{Japan}

Japan generated $\sim 42$ million tons of household and general commercial waste (referred to as MSW) in 2013 (MOEJ, 2015a). A compositional analysis revealed that $36 \%$ of household and commercial MSW in Japan is food waste, equivalent to 15 million tons of food waste. Although waste separation practices have been well established in Japan, few local governments currently source-separate household food waste from other waste. Therefore, despite the huge amount of household food waste generated ( $>10$ million tons/year), less than $6 \%$ is diverted for recycling (mainly composting), and $94 \%$ is sent to incinerators or landfills. This highlights the large improvements to recycling that implementation of further efforts could achieve (Liu et al., 2016). Despite the low percentage of MSW currently composted, the amount of MSW diverted for composting has increased since 2004 (MOEJ, 2015a), which may partially be ascribed to the implementation of the Promotion of Utilization of Recyclable Food Waste Act (Food Recycling Law) (MAFF, 2013a; Liu et al., 2016).

In addition to household food waste, commercial food waste is another major source of organic MSW. In the past decade, Japan's Food Recycling Law has promoted the proper management of commercial food waste. This law was enacted in 2001 with the aim of reducing food waste and promoting food waste recycling, for example by turning it into compost and livestock feed. Food waste from the manufacturing and processing stage, distribution stage (e.g., wholesaler and retailer), and consumption stage (e.g., food service businesses such as restaurants) falls within the scope of this law. In Japan, waste is mainly categorized as industrial waste or municipal waste. Food waste from the food manufacturing and processing stage is referred to as industrial waste, while that from the distribution and consumption stages is municipal waste. The law was revised in 2007 to further promote food waste recycling by requiring food waste generators to report the amount of recycled food waste, and to purchase farm products that use food waste-derived products, with the aim of establishing a food waste recycling loop (Takata et al., 2012).

The enforcement of the Food Recycling Law has significantly improved the food waste recycling rate. For example, 19.72 million tons of food waste was produced in 2013, of which 13.355 million tons $(68 \%)$ was recycled by methods regulated under the Food Recycling Law (MAFF, 2013b). The recycling rates for individual food waste generators, namely food manufacturers and processors, food wholesalers, retailers, and restaurants, were $78 \%$, $50 \%, 34 \%$, and $16 \%$, respectively. Based on these data, it is obvious that the enactment of the Food Recycling Law significantly enhanced food waste recycling rates; however, more improvements are necessary for municipal food waste recycling, especially from catering activities. This is possibly because municipal food waste is characterized as a dispersed emission source, comprises a relatively low mass, and is highly heterogeneous in content (Liu et al., 2016).

Of the recycling methods proposed by the Food Recycling Law, composting is highly recommended due to its relatively low environmental impact and high economic efficiency. This is particularly true for food waste generated in the consumption stage, which is generally of low quality, making it unsuitable for animal feed (Takata et al., 2012). According to statistical data from the Ministry of Agriculture, Forestry and Fisheries (MAFF, 2013b), over one-third ( 0.113 million tons) of recycled food consumption waste was composted. Despite the important role of composting in the municipal food waste recycling system, the majority of municipal food waste from catering activities and households is sent to landfills or incinerators. Therefore, future improvement efforts should focus on the collection and recycling of municipal food waste. 


\subsection{China}

With the rapid economic growth and massive urbanization in China, MSW treatment and disposal has become a serious problem. In 2013, 172 million tons of MSW was collected in China. Of this, $\sim 60 \%$ of MSW entered landfills, $\sim 30 \%$ was incinerated, and less than $2 \%$ was composted (National Bureau of Statistics of China, 2015). Although landfills dominate the MSW treatment system, incineration is becoming increasingly common, as it can handle mixed MSW well and allows for energy recovery, which partially compensates for the high capital and operational costs of such facilities. Compared with incineration, the amount of composted MSW decreased from 7.3 million tons in 2004 to 2.7 million tons in 2013 due to the low quality of the compost product, characterized by a lack of nutrients and elevated heavy metal levels (Wei et al., 2000; Cheng and $\mathrm{Hu}, 2010$ ). Detailed data on waste composting in China is shown in Fig. 1. The poor quality of compost derived from MSW in China may partially be ascribed to inefficient separation/sorting of the mixed waste or co-composting with sludge (Wei et al., 2000; Song and Chen, 2013). Co-composting with sewage sludge was a common practice in the 1990s in China. Adding sludge can facilitate MSW composting by providing microorganisms to drive the process. However, sewage treatment plants in China not only treat municipal wastewater, but also accept a proportion of industrial wastewater without sufficient pretreatment before entering the municipal wastewater plant, which could elevate heavy metal concentrations in sewage sludge (Yao et al., 2010).

Despite the decline in MSW composting, it is still expected that composting will reshape waste treatment schemes in China as source separation of MSW is gradually implemented throughout the country. The Chinese government has established national policies and regulations to promote source separation of MSW, including the Classification Symbols for Municipal Solid Waste (GB/T19095-2008) and Classification and Evaluation Standard of Municipal Solid Waste (CJJ/T102-2004). In addition, the Technical Guide for Treatment of Domestic Waste (MOHURD [2010] No. 61) released in 2010 noted that source-separated MSW collection should be implemented in more cities, and that biodegradable organic material should be recycled as a resource. The consultation paper System Plan to Compel Separation of Domestic Waste (NDRC [2016] No.1467) published in 2016 set quantitative targets for separate collection of MSW. For example, by 2020, all municipalities and provincial capitals will be forced to implement waste separation. Waste separation systems should cover at least $90 \%$ of the city area, and the waste recycling rate, including organic waste recycling, should reach $35 \%$.

Although source-separated collection systems have not been successfully established in any cities or districts in China, several pioneering cities are beginning to put waste source separation into practice (Tai et al., 2011). In 2000, the Chinese central government piloted a source-separated waste collection program in eight cities, Beijing, Shanghai, Guangzhou, Shenzhen, Hangzhou, Nanjing, Xiamen, and Guilin, requiring the local authorities to explore source-separated MSW collection. Tai et al. (2011) performed a comparative analysis of these eight cities and concluded that only Beijing and Shanghai demonstrated relatively effective results, while the other six cities had poor performances. Here, we use Shanghai as an example of the status of waste source separation development in China. Shanghai is a city with a high-density population, which produced 7.04 million tons of MSW in 2011 with an average annual rate of increase of $3.9 \%$. In 2007, waste sorting into four categories (glass, hazardous waste, recyclables, and others) was introduced. After a series of promotional activities to explore additional strategies, progress was made regarding the sorting and reduction of household waste. In 2011, a " $2+3$ " sorting scheme was implemented via a government project. First, waste was sorted into two streams, dry and wet. The dry waste was later divided into glass, textiles, and other waste. It should be noted that valuable dry recyclables were normally excluded, including plastic bottles, aluminum cans, and bulky cardboards, as they were recycled by scavengers. The wet waste mostly comprised food waste. Compared with the classification method introduced in 2007, this new method appeared to be more practical, as it was better accepted by residents.

China's 13th Five-Year Plan (2016-2020) (The State Council of the People's Republic of China, 2015) clearly states that sourceseparated collection of MSW and recycling of renewable resources should be promoted. Moreover, MSW in China normally contains a much higher percentage of kitchen waste, primarily as food waste (see Table 1 and Fig. 2); therefore, diverting food waste from the waste stream might help establish a practical and feasible sourceseparated collection system, similar to the $2+3$ sorting scheme carried out in Shanghai in 2011. Currently, there are few composting plants that process source-separated OFMSW or treat mixed MSW using mechanical equipment to separate the organic fraction. By implementing source separation, treatment of food waste using biological techniques, either composting or anaerobic digestion, is expected to gain more attention in the near future.

\section{Environmental concerns of MSW composting}

\subsection{Odors}

\subsubsection{Odor generation}

To quantify the effects of emitted odorants in humans, a series of standard methods (e.g., EN 13725, 2003) have been adopted. These methods measure the total odor impact presented as the odor concentration, but do not identify the chemicals responsible for the odor. However, the effects of different odorous compounds vary significantly, even at the same concentration (Tsai et al., 2008). Therefore, it is necessary to specify the compositional characteristics of the odorous gases. The major odor-causing compounds during composting are carbon-, nitrogen-, and sulfur-based, and include hydrogen sulfide, volatile organic sulfides, ammonia, pyridine, amines, hydrocarbons, terpenes, alcohols, ketones, aldehydes, and esters (Komilis et al., 2004; Mao et al., 2006; Zhang et al., 2013; Maulini-Duran et al., 2014a; Shao et al., 2014 Shao et al., 2014). The relative abundance of these compounds is dependent on the feeder material, composting process (i.e., open or closed), and conditions, such as moisture and aeration, as well as the composting stage (i.e., active composting phase or curing phase) and composting operations (e.g., shredding, screening, or turning).

Volatile organic compounds (VOCs) are a major source of odorous gas (Staley et al., 2006; Scaglia et al., 2011; Maulini-Duran et al., 2014a). The composition of VOCs in MSW composting plants has been studied intensively (Komilis et al., 2004; Scaglia et al., 2011; Maulini-Duran et al., 2014a). Although the relative abundances vary, the major compositions generally include terpenes, aliphatic hydrocarbons, aromatic hydrocarbons, alcohols, ketones, and esters. Fig. 4 shows the concentrations of the major odorous compounds. For each compound, the olfactory threshold (i.e., the minimum concentration of molecules resulting in the perception of odor) is provided. It should be emphasized that limonene and $p$-cymene are typical terpenes that are usually detected at concentrations much greater than their olfactory threshold values in composting facilities of OFMSW, underlining the importance of controlling terpenes for effective odor management (Eitzer, 1995; Staley et al., 2006; Tsai et al., 2008; Scaglia et al., 2011).

Ammonia, produced from the degradation of proteins, is a characteristic nitrogen-based odorous compound emitted in concentrations well over the threshold limit during composting 


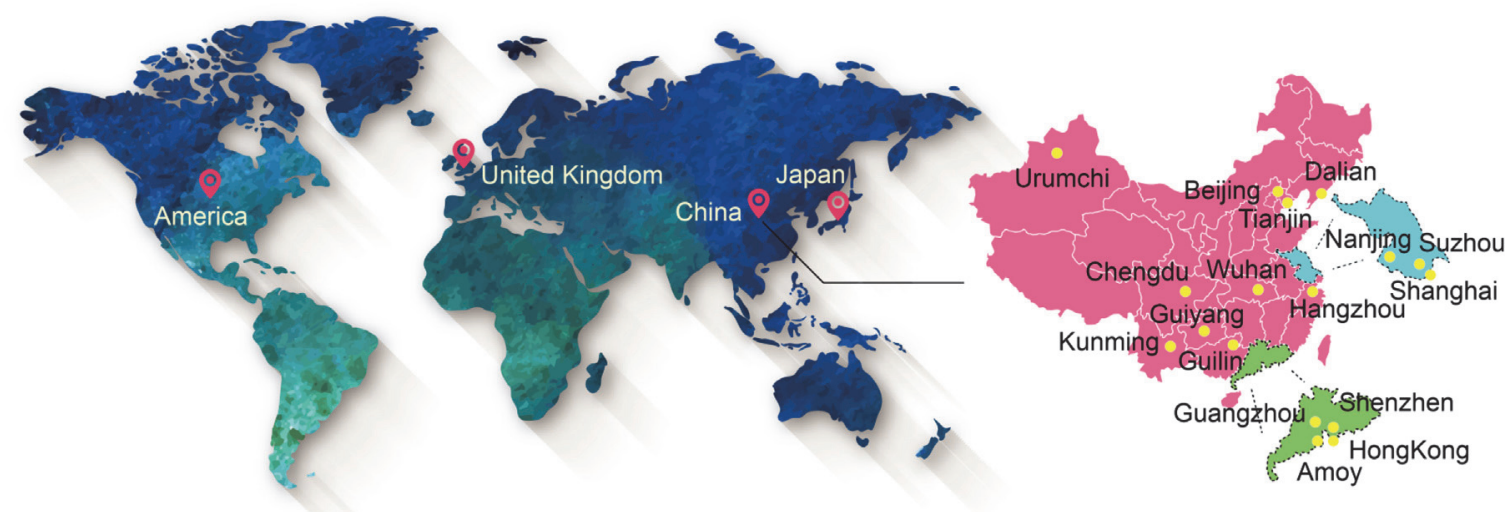

Fig. 2. Geographical locations of the countries and cities included in Fig. 1 and Table 1.
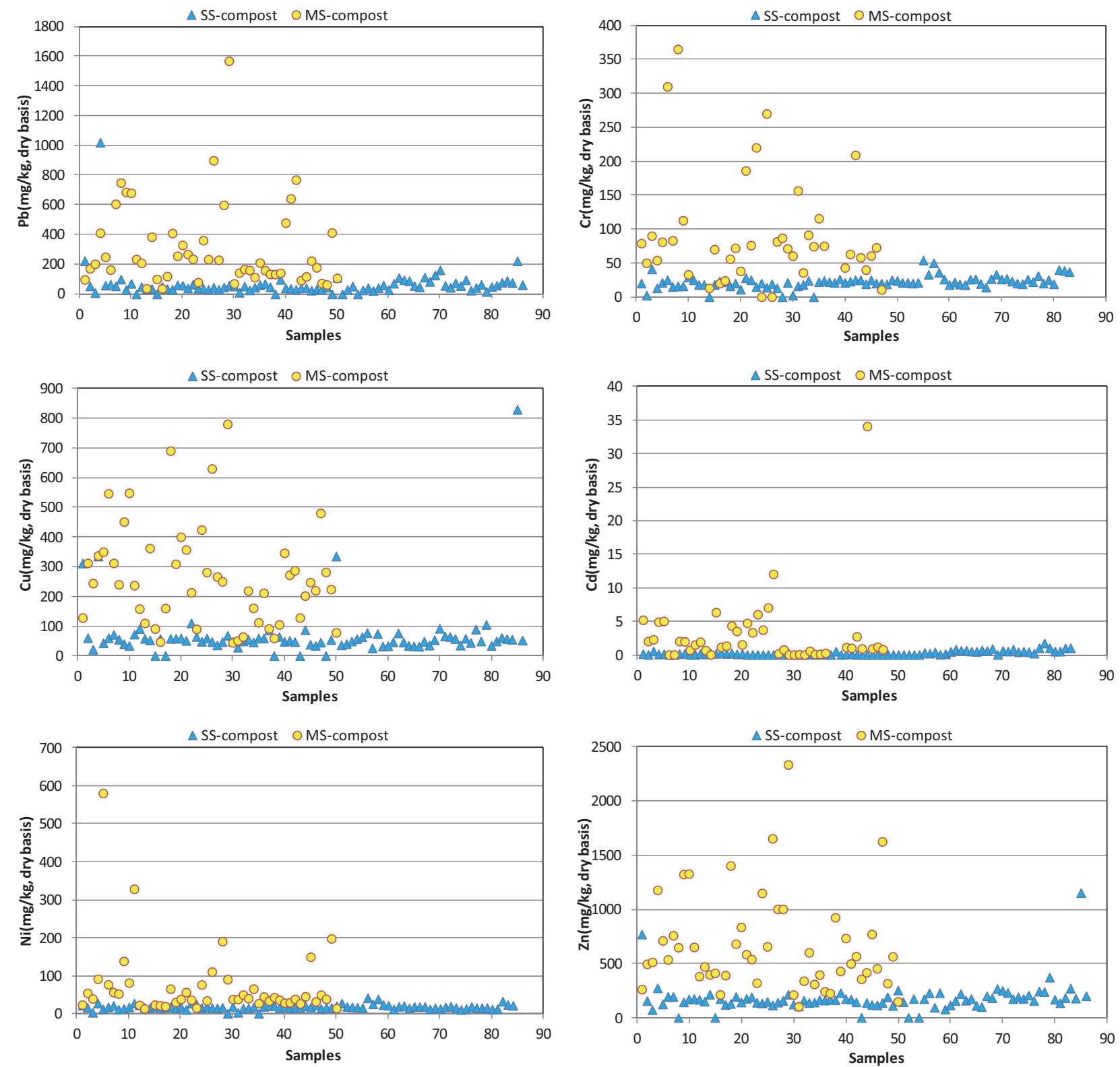

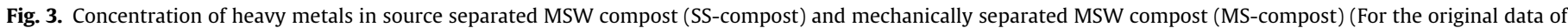
this figure, you may refer to the supplementary information). 
Table 1

Typical composition of MSW in the USA, UK, Japan and China (Geographical location of the 4 countries and 17 cities of China was marked in Fig. 2).

\begin{tabular}{|c|c|c|c|c|c|c|c|c|c|c|c|c|c|}
\hline \multirow[b]{2}{*}{ Country } & \multirow[b]{2}{*}{ Data source } & \multirow[b]{2}{*}{ Year } & \multirow[b]{2}{*}{$\begin{array}{l}\text { Food } \\
\text { scraps }\end{array}$} & \multicolumn{8}{|c|}{ Proportion of components(wt\%) } & \multirow[b]{2}{*}{$\begin{array}{l}\text { Water } \\
\text { Content(\%) }\end{array}$} & \multirow[b]{2}{*}{ References } \\
\hline & & & & & Paper & Plastics & Glass & Metals & Textiles & Wood & Other & & \\
\hline USA & National level & 2013 & 14.60 & 13.50 & 27.00 & 12.80 & 4.50 & 9.10 & 9.00 & 6.20 & 3.30 & & USEPA (2013) \\
\hline UK & National level & 2010-2011 & 16.76 & 16.54 & 19.20 & 10.45 & 6.85 & 3.69 & $2.94^{\mathrm{a}}$ & 3.82 & 19.75 & & DEFRA (2013) \\
\hline \multirow[t]{9}{*}{ Japan } & National level & 2015 & 36.10 & & 32.80 & 10.50 & 4.80 & 3.80 & 4.20 & 4.40 & 3.40 & & MOEJ (2015b) \\
\hline & Beijing & 2008 & 69.30 & & 10.30 & 9.80 & 0.60 & 0.80 & 1.30 & 2.70 & 5.20 & 50.00 & Qu et al. (2009) \\
\hline & Tianjin & 2010 & 77.24 & & 8.41 & 7.83 & 0.85 & 0.48 & 1.24 & 1.59 & 2.36 & & Zhou et al. (2015) \\
\hline & Shanghai & 2006 & 55.00 & & 4.00 & 33.00 & 3.00 & & 3.00 & 2.00 & & & Zhu et al. (2009) \\
\hline & Shenzhen & 2010 & 44.10 & & 15.34 & $21.72^{\mathrm{b}}$ & 2.53 & 0.47 & $7.40^{\mathrm{a}}$ & 1.41 & 7.01 & 53.25 & Huang (2012) \\
\hline & Amoy & 2007 & 62.80 & & 6.00 & 9.60 & 2.30 & 0.60 & 2.00 & 0.60 & 15.30 & & Chen and Liu (2010) \\
\hline & Guangzhou & 2011 & 37.76 & & 8.10 & 25.55 & 1.37 & 0.66 & 20.44 & 2.60 & 3.52 & & Tang et al. (2012) \\
\hline & Hangzhou & 2006 & 64.48 & & 6.71 & 10.12 & 2.02 & 0.31 & 1.22 & 0.05 & 15.09 & 53.60 & Zhuang et al. (2008) \\
\hline & Chengdu & 2011 & 65.70 & & 13.00 & 12.00 & 0.80 & & $2.50^{\mathrm{a}}$ & 0.88 & 5.00 & 57.30 & Huang and Liu (2012) \\
\hline \multirow[t]{10}{*}{ China $^{\mathrm{d}}$} & Dalian & 2007 & 59.86 & & 14.39 & 16.19 & & 0.69 & 4.67 & 2.10 & 2.10 & 61.74 & Li et al. (2008) \\
\hline & Wuhan & 2006 & 57.58 & & 8.31 & 9.62 & 2.76 & 0.35 & 1.81 & 6.18 & 13.39 & & Zhou et al. (2015) \\
\hline & Suzhou & 2011-2012 & 65.70 & & 14.30 & 8.90 & 2.10 & 1.50 & 2.30 & 0.40 & 4.80 & 59.44 & Gu et al. (2015) \\
\hline & Nanjing & 2008 & 70.59 & & 8.32 & 14.18 & 1.45 & 0.08 & 3.05 & 1.04 & 1.29 & & Tai et al. (2011) \\
\hline & Guilin & 2008 & 61.31 & & 4.96 & 28.18 & 1.94 & & & & 3.61 & & Tai et al. (2011) \\
\hline & Kunming & 2008 & 37.51 & & 2.68 & 5.13 & 1.20 & 2.58 & 1.85 & 7.15 & 41.92 & & Zhang et al. (2004) \\
\hline & Guiyang & 2008 & 41.97 & & 7.96 & 7.46 & & & 1.21 & 0.45 & $40.90^{c}$ & & Xiao et al. (2009) \\
\hline & Urumchi & 2008 & 75.95 & & 2.41 & 5.37 & 2.41 & 0.75 & 4.19 & 2.53 & 6.39 & 47.02 & Shao et al. (2009) \\
\hline & HongKong & 2006 & 44.00 & & 26.00 & 18.00 & 3.00 & 2.00 & 3.00 & 1.00 & 3.00 & & Ping and Chi (2009) \\
\hline & Avg. & & 58.29 & & 9.48 & 14.27 & 1.89 & 0.87 & 3.91 & 2.04 & 10.68 & 54.62 & \\
\hline
\end{tabular}

a Texitiles.

b Rubebr and plastics.

c Including metals, glass and other inorganics.

d No national level data is available, thus data of 17 cities was used to calculate an average value.

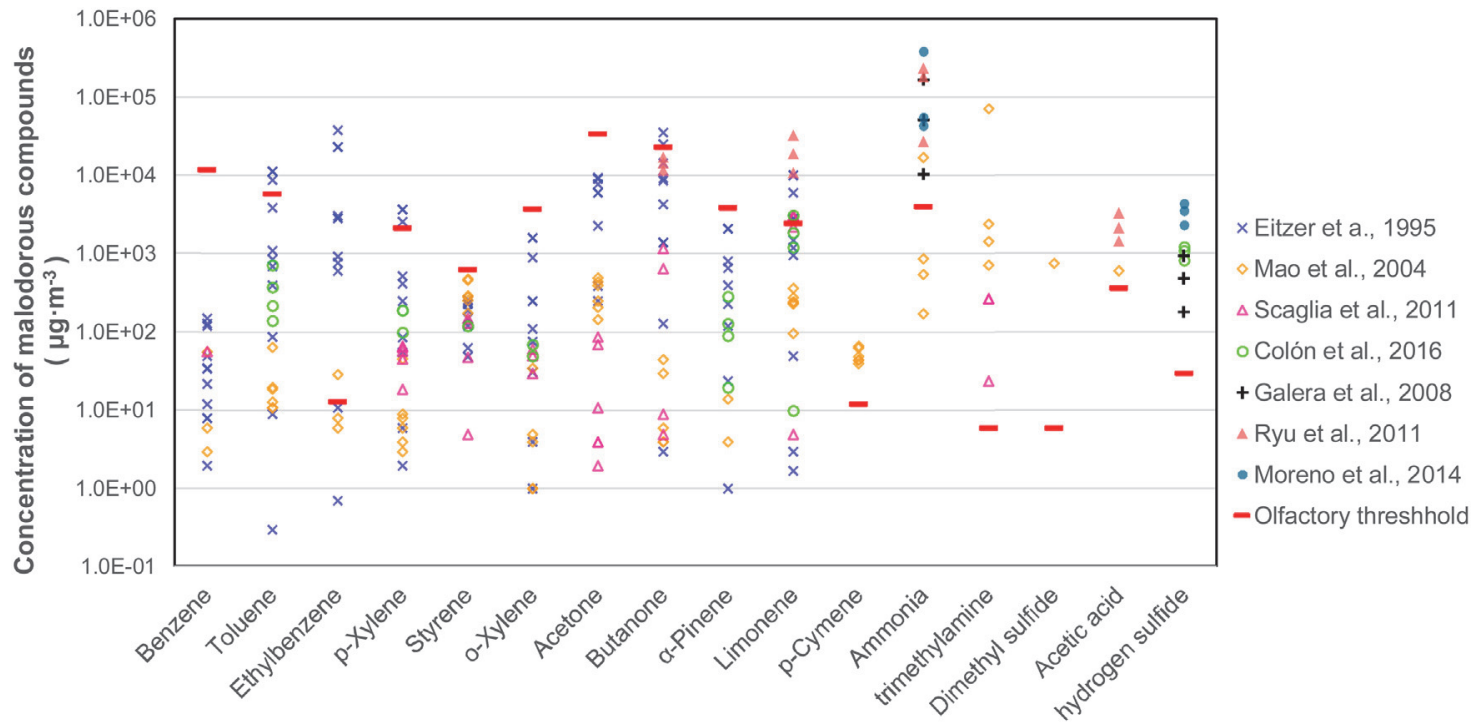

Fig. 4. Concentration of malodorous compounds in MSW composting plants (The olfactory threshold value for each compound was cited from Eitzer, 1995).

(Pagans et al., 2006). The release of ammonia is highly dependent on the temperature and $\mathrm{pH}$ of the composting pile, while higher temperature and $\mathrm{pH}$ favor ammonia vaporization by changing the ammonium-ammonia equilibrium (Pagans et al., 2006). Moreover, the release of ammonia is related to the nitrogen content in the raw material, and higher nitrogen contents normally result in the production of more ammonia (Jiang et al., 2011). The food waste in MSW is characterized by a low carbon-to-nitrogen ratio (Adhikari et al., 2008 and references therein), resulting in the generation of ammonia. Several studies have provided evidence that ammonia is a major odorous compound, with the highest concentration of odorous compounds emitted from food waste composting processes (Komilis and Ham, 2006; Mao et al., 2006; Tsai et al., 2008; Galera et al., 2008; Ryu et al., 2011). In addition to ammonia, several other organic nitrogen-based compounds are important due to their extremely low olfactory thresholds and high olfactometry-based odor concentrations at low concentrations, such as trimethylamine, with an olfactory threshold of 0.002 ppm (Devos et al., 1990) and an olfactometry-based odor concentration of 21,000 at $5 \mathrm{ppm}$ (Tsai et al., 2008). Moreover, high amine levels have been detected in composting plants. For example, 300-30,000 ppb of amines was measured in a commercial-scale food waste treatment plant (Tsai et al., 2008). Fig. 4 shows that, in most cases, ammonia and trimethylamine exceeded the olfactory threshold values, indicative of the substantial contribution of nitrogen-based compounds to odor concentrations.

In addition to carbon- and nitrogen-based compounds, sulfurbased compounds have been identified as significant sources of odorants in composting plants due to their very low olfactory thresholds (Devos et al., 1990; Tsai et al., 2008; Zhang et al., 2013), 
such as dimethyl sulfide with an olfactory threshold of $0.002 \mathrm{ppm}$ (Devos et al., 1990) and an olfactometry-based odor concentration of 1000 at 5 ppm (Tsai et al., 2008). This is particularly true when food waste is used as the major composting material (Komilis et al., 2004; Zhang et al., 2013). Zhang et al. (2013) systematically analyzed the volatile sulfur compounds (VSCs) produced during the composting of OFMSW, source-separated kitchen waste, and source-separated kitchen waste mixed with dry cornstalks in labscale reactors. They detected hydrogen sulfide, methyl mercaptan, dimethyl sulfide, carbon bisulfide, and dimethyl disulfide (DMDS) in all treatments, of which hydrogen sulfide was the most abundant compound, accounting for $39 \%$ to $43 \%$ of the total VSCs released. Follow-up research further revealed the predominance of hydrogen sulfide in VSCs (Zhang et al., 2016). Two studies (Mao et al., 2006; Tsai et al., 2008) found that dimethyl sulfide was the major VSC, while Maulini-Duran et al. (2014a) and Ryu et al. (2011) reported DMDS as the major VSC. Conversely, Zhang et al. (2011) found that methyl mercaptan was the major VSC produced during food waste composting. These results differed substantially from those reported by Zhang et al. (2013), which could be explained by several factors. First, some research did not consider all VSCs, and the analytical methods varied among the studies. For example, Maulini-Duran et al. (2014a) and Ryu et al. (2011) only analyzed DMDS. Second, sulfur compounds are mainly generated from the biodegradation of sulfur-containing proteins during composting (Komilis et al., 2004). Therefore, the composition and characteristics of the composting material may significantly influence VSC profiles. Third, temperature and aeration rates greatly affect the microbial community during composting (Hort et al., 2013; Zhang et al., 2016), which consequently affects the forms and emissions fluxes of the derivative VSCs. In fact, within the same composting pile, the forms and emissions fluxes of VSCs have been shown to fluctuate over time (Zhang et al., 2016).

\subsubsection{Odor control strategies}

4.1.2.1. Odor prevention during composting. Odors are inherent byproducts of composting regardless of the initial organic material, composting technologies, and operation conditions adopted. Nevertheless, odor generation can be reduced by optimizing the composting pile or windrow conditions. Of all possible odor generation prevention measures, maintaining optimal aeration is particularly important, because it limits the formation of anaerobic zones, avoiding the production of anaerobic metabolism intermediates. Traditional aeration control options include oxygen feedback controls and cyclic on/off aeration. Puyuelo et al. (2010) proposed a novel control strategy to optimize oxygen supply based on biological activity, measured as the oxygen uptake rate (OUR). Maulini-Duran et al. (2014b) adopted this strategy to evaluate its effects on VOC generation, and found that while the OUR controller showed no obvious effects on VOC inhibition, the resulting VOC emissions profile showed less variation.

Compared with aeration optimization, adding various bulking agents, such as cornstalks, rice straw, wheat straw, wood chips, and sawdust, seems to be more effective and practical for odor prevention, since bulking agents have additional functions of moisture adjustment, nutrient equilibration, improving pile strength, and increasing porosity for oxygen (Awasthi et al., 2015). Zhang et al. (2013) found that adding cornstalks to source-separated kitchen waste significantly reduced VSC emissions. In addition to cornstalks, rice straw was found to significantly reduce malodorous sulfur compound emissions. Moreover, a positive effect on other odorous compounds, including VOCs and ammonia, was detected (Shao et al., 2014). Meanwhile, Yuan et al. (2015) observed that bulking agents had a positive effect on odorous gas emission control. They evaluated the effects of adding dry cornstalks as a bulking agent in combination with chemical pretreatment with ferric chloride to decrease ammonia and hydrogen sulfide emissions during kitchen waste composting. They found that the addition of cornstalks reduced hydrogen sulfide emissions, similar to the observations by Zhang et al. (2013), but had little impact on ammonia. However, the addition of ferric chloride significantly decreased both ammonia and hydrogen sulfide emissions, while kitchen waste with both cornstalks and ferric chloride exhibited the greatest reductions in ammonia and hydrogen sulfide production. Regardless, controversy still exists regarding the efficacy of bulking agents for odor prevention. Yang et al. (2013) found that the addition of three bulking agents, cornstalks, sawdust, and spent mushroom substrate, to kitchen waste had no obvious effects on ammonia emissions. Maulini-Duran et al. (2014a) evaluated the effects of wood chips on gaseous emissions in municipal waste composting, and observed that they slightly decreased VOC emissions, but significantly increased ammonia emissions without offering any explanation. Table 2 compares the bulking agents that have been used for odor prevention during composting.

Although there is no consensus regarding bulking agents for odor prevention, generally it is accepted that degradable bulking agents, such as cornstalks and rice straw, are effective for controlling sulfur-containing malodors. Several possible mechanisms have been proposed (Shao et al., 2014). For example, the addition of bulking agents may provide a physical structure that enables gas transfer throughout the composting pile, which could improve oxygen diffusion. Moreover, the addition of bulking agents may decrease the proportion of readily biodegradable organics in the feedstock, which could decrease the oxygen consumption rate and prevent the formation of anaerobic zones if adequate oxygen is not supplied immediately. The latter mechanism is particularly important when composting MSW with a high proportion of food waste; however, the combined effects of these two mechanisms contribute to the reduction of sulfur-containing malodors.

4.1.2.2. End-of-pipe odor control. In addition to odor prevention by optimizing composting conditions, several end-of-pipe measures are commonly adopted, including the use of airtight composting reactors, gas collection with negative pressure, and deodorization processes. It is generally agreed that in-vessel composting better promotes odor control compared with open composting; therefore, in-vessel composting facilities are becoming more common as more food waste is diverted to composting systems (AFOR, 2009). Furthermore, since the creation of technologies allowing the collection of outflow airstreams in composting plants, biofiltration has become a widely accepted technology for the final removal of malodorous compounds because of its capacity to treat low concentrations of diverse pollutants, cost-effectiveness, simple operation, and absence of secondary contaminated waste streams (López et al., 2011). Bindra et al. (2015) performed a systematic assessment of various odor control systems, including biofilters, packed tower wet scrubbers, fine mist wet scrubbers, activated carbon adsorption, thermal oxidization, oxidization chemicals, and masking agents. They found that biofiltration systems were the best option for organic processing facilities.

During biofiltration, the malodorous gas stream passes through filtration media, where the malodorous gases are adsorbed and biologically degraded into nontoxic end-products, such as carbon dioxide, water, and biomass (Galera et al., 2008). The filtration media generally consists of one or more beds of solid biologically active material, such as mature compost, peat, wood bark, wood chips, soil, sludge, synthetic media, or a combination of these products (Schlegelmilch et al., 2005; Pagans et al., 2006; Yin and Xu, 2009; López et al., 2011; Ryu et al., 2011; Hort et al., 2013). Numerous lab-, pilot-, and full-scale studies have shown the effectiveness of various biofiltration systems on the removal of various carbon-, nitrogen- and sulfur-based malodors (Schlegelmilch et al., 2005; 
Table 2

A summary of the various bulking agents on odor prevention.

\begin{tabular}{|c|c|c|c|c|c|c|}
\hline Reference & Waste type:bulking agent (ratio) & Scale & VSCs & $\mathrm{NH}_{3}$ & VOC & Descriptions \\
\hline Zhang et al. (2013) & Kitchen waste: cornstalks ( $4: 1)$ & Lab-scale 20L & $\sqrt{ }$ & NA & NA & $\begin{array}{l}\text { Addition of dry cornstalks significantly } \\
\text { reduced the VSCs emissions. Compared } \\
\text { to pure kitchen waste, VSCs were } \\
\text { reduced } 66.8 \% \text {. }\end{array}$ \\
\hline Shao et al. (2014) & $\begin{array}{l}\text { OFMSW:rice straw }(10: 1,10: 2 \text {, and } \\
10: 3)\end{array}$ & Pilot-scale & $\sqrt{ }$ & $\sqrt{ }$ & $\sqrt{ }$ & $\begin{array}{l}\text { The total cumulative emission fluxes of } \\
\text { VSCs were } 0.81,0.57 \text { and } 0.37 \mathrm{mg} / \mathrm{dry} \text { kg } \\
\text { of composting mixtures, respectively. For } \\
\text { ammonia were } 13.57,11.72 \text { and } \\
8.14 \mathrm{mg} / \mathrm{dry} \text { kg of composting mixtures, } \\
\text { respectively. For VFAs were } 0.16,0.016 \\
\text { and } 0.098 \mathrm{mg} / \mathrm{dry} \mathrm{kg} \text { of composting } \\
\text { mixtures, respectively. For alcohols were } \\
0.81,0.18 \text { and } 0.27 \mathrm{mg} / \mathrm{dry} \text { kg of } \\
\text { composting mixtures, respectively. For } \\
\text { terpenes from were } 3.34,1.77 \text { and } \\
0.98 \mathrm{mg} / \mathrm{dry} \text { kg of composting mixtures, } \\
\text { respectively For aldehydes and ketones } \\
\text { were } 11.97,3.09 \text { and } 2.87 \mathrm{mg} / \mathrm{dry} \text { kg of } \\
\text { composting mixtures, respectively. }\end{array}$ \\
\hline Yuan et al. (2015) & $\begin{array}{l}\text { Kitchen waste: dry cornstalks ( } 8.5: 1.5 \\
\text { by web basis) }\end{array}$ & Lab-scale 20L & $\sqrt{ }$ & $\bigcirc$ & NA & $\begin{array}{l}\text { The presence of cornstalks caused less } \\
\mathrm{H}_{2} \mathrm{~S} \text { to be emitted, but had little impact } \\
\text { on the amount of } \mathrm{NH}_{3} \text { emitted }\end{array}$ \\
\hline Yuan et al. (2015) & $\begin{array}{l}\text { Kitchen waste: chemical agent of ferric } \\
\text { chloride ( } \mathrm{Fe}^{3} \text { was added at } 10 \% \text { of TN of } \\
\text { the raw materials by molar mass) }\end{array}$ & Lab-scale 20L & $\sqrt{ }$ & $\sqrt{ }$ & NA & $\begin{array}{l}\text { The } \mathrm{FeCl}_{3} \text { was found to act as an effective } \\
\text { chemical flocculant, and its presence } \\
\text { significantly decreased the amounts of } \\
\mathrm{NH}_{3} \text { and } \mathrm{H}_{2} \mathrm{~S} \text { emitted. }\end{array}$ \\
\hline Yuan et al. (2015) & $\begin{array}{l}\text { Kitchen waste with dry cornstalks and } \\
\text { chemical pretreated with ferric } \\
\text { chloride (a combined addition of the } \\
\text { above two scenarios) }\end{array}$ & Lab-scale 20L & $\sqrt{ }$ & $\sqrt{ }$ & NA & $\begin{array}{l}\text { Kitchen waste mixed with cornstalks and } \\
\text { treated with } \mathrm{FeCl}_{3} \text { emitted } 42 \% \text { less } \mathrm{NH}_{3} \\
\text { and } 76 \% \text { less } \mathrm{H}_{2} \mathrm{~S} \text { during composting than } \\
\text { did pure kitchen waste. }\end{array}$ \\
\hline $\begin{array}{l}\text { Maulini-Duran et al. } \\
\text { (2014a) }\end{array}$ & OFMSW: wood chips (not stated) & Pilot-scale50L & NA & $\mathrm{X}$ & $\bigcirc$ & $\begin{array}{l}\text { The emission status was in comparison } \\
\text { with non-source collected MSW. }\end{array}$ \\
\hline $\begin{array}{l}\text { Maulini-Duran et al. } \\
\text { (2014b) }\end{array}$ & $\begin{array}{l}\text { OFMSW: polyethylene tube (not } \\
\text { stated) }\end{array}$ & Pilot-scale50L & NA & $\sqrt{ }$ & $\sqrt{ }$ & $\begin{array}{l}\text { The emission status was in comparison } \\
\text { with non-source collected MSW. }\end{array}$ \\
\hline Yang et al. (2013) & Kitchen waste: cornstalks (not stated) & Lab-scale 60L & NA & $\mathrm{X}$ & NA & $\begin{array}{l}\text { The bulking agents increased compost } \\
\text { maturity, but had little impact on } \mathrm{NH}_{3} \\
\text { emissions. }\end{array}$ \\
\hline
\end{tabular}

NA: not analyzed; $\sqrt{ }$ : positive effect; $\bigcirc$ : no obvious effect; $x$ : negative effect.

Galera et al., 2008; Ryu et al., 2011; Hort et al., 2013); a summary of these studies is provided in Table 3. Ryu et al. (2011) reported a high removal efficiency for both ammonia and VOC malodorous gas generated in a food waste composting plant via a polyurethane-mediated lab-scale biofilter. With inlet concentrations of 40-350 ppm, the outlet ammonia concentration was below $2 \mathrm{ppm}$, equivalent to a removal efficiency of up to $99 \%$. In addition, the outlet VOC concentration was below $4 \mathrm{ppm}$, with an inlet concentration of 38-105 ppm, showing a removal efficiency of up to 95-99\%. Schlegelmilch et al. (2005) evaluated the odor removal ability of a combined bioscrubber/biofiltration system with two bedding materials. The biofilter media were composed of mature screened compost $(>20 \mathrm{~mm})$ and coke coated with a thin layer of fine compost. The coke had a particle size of $\sim 50 \mathrm{~mm}$ and the compost layer was $\sim 3 \mathrm{~mm}$ thick. The addition of the bioscrubber buffered the high malodor concentration in the inlet gas flow of the biofilter. For example, at a mean air load of $\sim 140 \mathrm{~m}^{3} \mathrm{~m}^{-3} \mathrm{~h}^{-1}$, the screened compost-mediated treatment system showed a higher degradation efficiency of VOCs (99\%) than the coke-compostmediated system (95\%), both of which were significantly higher than the single bioscrubber system (28\%), demonstrating the efficacy of biofilters for odor degradation. Moreover, a full-scale open biofilter reported in the same literature proved to be efficient for odor degradation. Another industrial-scale biofilter packed with mature yard waste compost showed a $100 \%$ removal efficiency of sulfur compounds (Hort et al., 2013).

The lower removal efficiency of malodorous compounds in some studies (Pagans et al., 2006; Hort et al., 2013) may partially be ascribed to the fact that biofilters alone emit odorous pollutants; other factors include compositional fluctuations, loading variation of the inlet gas, and drying of the filter medium. A moisture content of $30-60 \%$ (wet basis) is recommended to maximize the removal efficiency of malodors, which is optimal for microbial activity in organic filter media. Failure to control moisture levels results in a decreased removal efficiency of target compounds (Hort et al., 2013).

Several mechanisms underlying the removal of malodors by biofiltration have been elucidated. Since most VOCs are products of biological degradation processes (Eitzer, 1995; Schlegelmilch et al., 2005), further biological decomposition of these compounds is possible with biofiltration systems. Yin and Xu (2009) found that ammonia removal in biofilters could be ascribed to ammoniaoxidizing bacteria, which transformed ammonia into nitrate. In addition, the end-products of the oxidation of sulfur-containing malodors are sulfates $\left(\mathrm{SO}_{4}{ }^{2-}\right)$, thiosulfates $\left(\mathrm{S}_{2} \mathrm{O}_{3}{ }^{2-}\right)$, and elemental sulfur $\left(\mathrm{S}^{00}\right)$ (Hort et al., 2013).

\subsection{Bioaerosols}

\subsubsection{Bioaerosol generation}

Microbiological activity, such as metabolism, growth, and reproduction, are fundamental to composting; therefore, any handling (e.g., waste loading and unloading, blending and mixing, turning, mixing, aeration, and screening) of composting material is likely to release substantial quantities of airborne microorganisms, or bioaerosols, which may pose potential risks (e.g., respiratory dis- 
Table 3

A summary of the various biofiltration systems for removal of composting sourced malodors.

\begin{tabular}{|c|c|c|c|c|c|c|}
\hline \multirow[b]{2}{*}{ Reference } & \multirow[b]{2}{*}{ Process } & \multirow[b]{2}{*}{ Scale } & \multirow[b]{2}{*}{ Packing materials } & \multicolumn{3}{|c|}{ Removal effect of malodors } \\
\hline & & & & $\mathrm{C}-$ & $\mathrm{N}-$ & S- \\
\hline Pagans et al. (2006) & Biofiltration & Lab scale & Manure compost & $<57 \%$ & NA & NA \\
\hline Chung (2007) & Biofiltration & Lab scale & $\begin{array}{l}\text { Mature compost mixed with } \\
\text { activated carbon inoculated } \\
\text { with sludge }\end{array}$ & $>97 \%$ & $>95 \%$ & $>90 \%$ \\
\hline Yin and Xu (2009) & Biofiltration & Lab scale & $\begin{array}{l}\text { Compost amended with } 20 \% \text { of } \\
\text { perlite and inoculated with } \\
\text { nitrifying activated sludge }\end{array}$ & NA & NA & $97-99 \%$ \\
\hline Yin and Xu (2009) & Biofiltration & Lab scale & $\begin{array}{l}\text { Sludge amended with } 20 \% \\
\text { granular activated carbon and } \\
\text { inoculated with nitrifying } \\
\text { activated sludge }\end{array}$ & NA & NA & $95-99 \%$ \\
\hline Hernández et al. (2010) & Biofiltration & Lab scale & $\begin{array}{l}\text { Spherical argyle pellets } \\
\text { covered with compost, } \\
\text { inoculated with microbial } \\
\text { culture }\end{array}$ & avg.94\% & $66-100 \%$ & $\begin{array}{l}\text { avg.91\% for } \\
\text { DMS;avg.93\% for } \\
\text { DMDS }\end{array}$ \\
\hline Hernández et al. (2010) & Biofiltration & Lab scale & $\begin{array}{l}\text { Spherical argyle pellets } \\
\text { covered with compost, } \\
\text { inoculated with sludge }\end{array}$ & avg.91\% & $80-100 \%$ & $\begin{array}{l}\text { avg. } 89 \% \text { for } \\
\text { DMS;avg. } 89 \% \text { for } \\
\text { DMDS }\end{array}$ \\
\hline Hernández et al. (2010) & Biofiltration & Lab scale & $\begin{array}{l}\text { Pine bark inoculated with } \\
\text { microbial culture }\end{array}$ & avg. $85 \%$ & $74-100 \%$ & $\begin{array}{l}\text { avg.84\% for } \\
\text { DMS;avg.89\% for } \\
\text { DMDS }\end{array}$ \\
\hline Ryu et al. (2011) & Biofiltration & Lab scale & $\begin{array}{l}\text { Polyurethane inoculated with } \\
\text { activated sludge }\end{array}$ & $95 \%-99 \%$ & $>99 \%$ & NA \\
\hline Hort et al. (2013) & Biofiltration & Lab scale & $\begin{array}{l}\text { A mixture of mature compost } \\
\text { with sewage sludge and yard } \\
\text { waste }\end{array}$ & NA & NA & $\begin{array}{l}60-99 \% \text { for } \\
\mathrm{H}_{2} \mathrm{~S} ; 70-95 \% \text { for } \\
\mathrm{MeSH} ; 5-99 \% \text { for } \\
\mathrm{Me}_{2} \mathrm{~S}\end{array}$ \\
\hline Hort et al. (2013) & Biofiltration & Lab scale & $\begin{array}{l}\text { Mature compost with yard } \\
\text { waste }\end{array}$ & NA & NA & $\begin{array}{l}\text { 70-99\% for } \\
\mathrm{H}_{2} \mathrm{~S} ; 80-95 \% \text { for } \\
\mathrm{MeSH} ; 10-99 \% \text { for } \\
\mathrm{Me}_{2} \mathrm{~S}\end{array}$ \\
\hline $\begin{array}{l}\text { Schlegelmilch et al. } \\
\text { (2005) }\end{array}$ & Bioscrubber/biofiltration & Technical scale & $\begin{array}{l}\text { Matured screened compost } \\
(>20 \mathrm{~mm})\end{array}$ & $97 \%$ & NA & NA \\
\hline $\begin{array}{l}\text { Schlegelmilch et al. } \\
\text { (2005) }\end{array}$ & Bioscrubber/biofiltration & Technical scale & $\begin{array}{l}\text { Coke coated with a thin layer } \\
\text { of fine compost }\end{array}$ & $99 \%$ & NA & NA \\
\hline $\begin{array}{l}\text { Schlegelmilch et al. } \\
\text { (2005) }\end{array}$ & $\begin{array}{l}\text { Wet scrubber/open single } \\
\text { bed biofilter }\end{array}$ & Full scale & Root wood & $96 \%$ & NA & NA \\
\hline Hort et al. (2013) & Biofiltration & Industrial scale & $\begin{array}{l}\text { Mature compost with yard } \\
\text { waste }\end{array}$ & NA & NA & $100 \%$ \\
\hline
\end{tabular}

NA: not analyzed.

ease) to composting plant workers and adjacent residents (Swan et al., 2003; Stagg et al., 2010; Pankhurst et al., 2011; Pearson et al., 2015). Bioaerosols comprise a collection of viable and nonviable microorganisms suspended in air, including fungi (typically Aspergillus fumigatus and Penicillium sp.) and fungal spores, bacteria (e.g., Firmicutes, Actinomycetes, and Proteobacteria) and bacterial spores, microbial fragments (primarily endotoxins and glucans), and metabolic products (e.g., mycotoxins) (Douwes et al., 2003; Albrecht et al., 2007; Sykes et al., 2011; Wéry, 2014; Pearson et al., 2015). Our understanding of the composition of bioaerosols has rapidly increased in the past 10 years due to the application of culture-independent molecular techniques for microbial analyses. Such analytical techniques compensate for the shortage of traditional culture-dependent approaches. More detailed information regarding the microbial diversity of composting bioaerosols is summarized by Wéry (2014).

Bioaerosol concentrations are highly related to on-site activities, including turning, shredding, and screening (Taha et al., 2006; Fischer et al., 2008; Pankhurst et al., 2011; van Kampen et al., 2014; Pearson et al., 2015). Bioaerosols generated at composting plants contain up to $8 \times 10^{6}$ colony forming units (cfu) of bacteria and $2 \times 10^{7}$ cfu of molds per cubic meter (Albrecht et al., 2007). To evaluate the bioaerosol concentrations in specific areas in worksites, a field study was conducted in 31 composting plants, including 124 inhalable dust samples. The highest levels of most of the parameters analyzed (e.g., dust, particles, antigens, endotoxin, and pyrogenic activity) were detected in dusty working areas, such as areas next to the shredder, and during processing operations (van Kampen et al., 2014). Another study (Taha et al., 2006) found that mixing activities resulted in the release of bioaerosols two to three orders of magnitude higher than those from static compost windrows. Meanwhile, Sykes et al. (2011) observed high levels of endotoxins and $\beta-1,3-$ glucan during all processes involving the movement of waste at four large-scale composting facilities.

\subsubsection{Bioaerosol control strategies}

4.2.2.1. Bioaerosol control in composting plants. Bioaerosols have been shown to penetrate deep into the lungs due to their small particle size (Byeon et al., 2008; O'Connor et al., 2015). Bünger et al. (2007) and van Kampen et al. (2012) evaluated the chronic effect of long-term exposure to organic dust (i.e., bioaerosol) on respiratory disorders and lung function among employees at 41 and 31 composting plants, respectively, in Germany, and found that the prevalence of mucosal membrane irritation of the eyes and upper airways in compost facility workers was highly associated with organic dust levels at the workplace. It should be noted that non-viable cells or microbial fragments, including endotoxins, peptidoglycans, $\beta$-(1,3)-D-glucan, and mycotoxins, can trigger health effects in exposed workers, including allergies or toxic reactions (Sykes et al., 2011).

Based on the exposure and heath effects of bioaerosols, robust approaches will likely be adopted to reduce occupational exposure 
Table 4

Maximum acceptable metal concentrations for compost in different countries ( $\mathrm{mg} / \mathrm{kg}$ dry matter).

\begin{tabular}{|c|c|c|c|c|c|c|c|c|c|c|c|c|}
\hline Country & Compost type & $\mathrm{Cd}$ & $\mathrm{Cu}$ & $\mathrm{Cr}$ & $\mathrm{Hg}$ & $\mathrm{Ni}$ & $\mathrm{Pb}$ & $\mathrm{Zn}$ & As & Se & Mo & Source \\
\hline UK & & 1.5 & 200 & 100 & 1 & 50 & 200 & 400 & & & & BSI-PAS 100:2011 \\
\hline Italy & & 1.5 & 150 & & 1.5 & 50 & 140 & 500 & & & & Law on Fertilisers L 748/84 \\
\hline Spain & A & 0.7 & 70 & 70 & 0.4 & 25 & 45 & 200 & & & & Spain RD 506/2013 \\
\hline Spain & B & 2 & 300 & 250 & 1.5 & 90 & 150 & 500 & & & & Spain RD 506/2013 \\
\hline Spain & $\mathrm{C}$ & 3 & 400 & 300 & 2.5 & 100 & 200 & 1000 & & & & Spain RD 506/2013 \\
\hline Germany & I & 1 & 70 & 70 & 0.7 & 35 & 100 & 300 & & & & Biowaste Ordinance \\
\hline Germany & II & 1.5 & 100 & 100 & 1 & 50 & 150 & 400 & & & & Biowaste Ordinance \\
\hline The Netherland & Compost & 0.7 & 25 & 50 & 0.2 & 10 & 65 & 75 & 5 & & & SDU 1991 \\
\hline The Netherland & Clean compost & 1 & 60 & 50 & 0.3 & 20 & 100 & 200 & 15 & & & SDU 1991 \\
\hline Switzerland & & 1 & 100 & 100 & & 30 & 120 & 400 & & & & $\begin{array}{l}\text { Swiss Federal council } \\
\text { (2013) }\end{array}$ \\
\hline California, USA & & 39 & 1500 & 1200 & 17 & 420 & 300 & 2800 & 41 & 36 & & CalRecycle \\
\hline USA & & 39 & 1500 & 1200 & 17 & 420 & 300 & 2800 & 41 & 100 & & $\begin{array}{l}\text { EPA standard for sewage } \\
\text { sludge and domestic } \\
\text { septage }\end{array}$ \\
\hline Canada & A & 3 & 400 & 210 & 0.8 & 62 & 150 & 700 & 13 & 2 & 5 & CCME 2005 \\
\hline Canada & B & 20 & 757 & 1060 & 5 & 180 & 500 & 1850 & 75 & 14 & 20 & CCME 2005 \\
\hline China & & 3 & & 300 & 5 & & 100 & & 30 & & & GB8172-87 \\
\hline
\end{tabular}

to organic dust, especially during waste mixing. Schlosser et al. (2012) suggested fitting the vehicle cabs of front-end loaders and mobile mixers in both indoor and outdoor composting facilities with a pressurization and high-efficiency particulate air (HEPA) filtration system to mitigate the occupational health risk associated with airborne bacteria, fungus, and endotoxin exposure. Moreover, regular thorough cleaning of the vehicle cab, as well as overalls and shoe cleaning, and mitigation of leakage in the filter-sealed system, are necessary to achieve high levels of protection.

4.2.2.2. Bioaerosol control outside composting plants. To evaluate the effects of bioaerosols on nearby residents, bioaerosols at different distances downwind of composting facilities were measured and compared with data monitored upwind or at background locations. In general, bioaerosol concentrations, usually represented by total bacteria and $A$. fumigatus, were noticeably higher immediately downwind of the composting facilities, and then gradually decreased as a result of dispersion (Pearson et al., 2015 and reference therein). In 13 community exposure studies reviewed by Pearson, several composting sites exceeded the UK Environment Agency's acceptable level of $1000 \mathrm{cfu} \mathrm{m}^{-3}$ for total bacteria and $500 \mathrm{cfu} \mathrm{m}^{-3}$ for $A$. fumigatus beyond $250 \mathrm{~m}$. Although there are limited reports on adverse health outcomes in residents in surrounding neighborhoods, elevated bioaerosol concentrations may increase the health risk to these neighborhoods, and should not be neglected.

Risk assessments based on bioaerosol dispersal are highly dependent on source bioaerosol concentrations, local topography, and meteorological conditions (Fischer et al., 2008; Pankhurst et al., 2012). Moreover, the indicators (e.g., viable total bacteria, gram negative bacteria, actinomycetes, total fungi, A. fumigatus, endotoxins, $\beta$-glucans, and organic dust) selected to trace bioaerosol concentrations may affect the accuracy of risk assessments. An effective indicator should be readily transformed into aerosols in high concentrations during composting operations and be specific or exclusive to composting environments (Wéry, 2014). Although numerous studies have attempted to identify effective bioaerosol indicators (Le Goff et al., 2012; Schäfer et al., 2013), no consensus has been reached. Due to these limitations, the reported distance at which composting bioaerosols remain detectable varies among studies (Fischer et al., 2008; Pankhurst et al., 2011, 2012). Regardless of such discrepancies and limitations, these studies have contributed greatly to the development of policies and regulatory guidelines for industrial composting. For example, the UK Environment Agency recommended that bioaerosol levels not exceed (i) those before the start of the composting process or (ii) $1000 \mathrm{cfu} \mathrm{m}^{-3}$ for total bacteria, $500 \mathrm{cfu} \mathrm{m}^{-3}$ for A. fumigatus, and $300 \mathrm{cfu} \mathrm{m}^{-3}$ for gram negative bacteria beyond $250 \mathrm{~m}$ from the site, for the authorization of new composting sites (UK Environment Agency, 2010).

\subsection{Heavy metals}

\subsubsection{Heavy metal generation}

Heavy metals in compost products are sourced from the raw materials subjected to composting. Thus, the method of waste collection (i.e., source-separated or mixed collection) and composition characteristics of the raw materials significantly affect the quality of the compost product. Based on a systematic analysis of heavy metals in compost, it is generally agreed that source-separated MSW compost can satisfy the legal criteria (Zheljazkov and Warman, 2004; Kupper et al., 2014); however, there is no such consensus for mechanically separated compost. Montejo et al. (2015) analyzed 30 compost samples from 10 mechanical biological treatment (MBT) plants with treatment capacities of 25,400 210,000 tons/year located in Spain, and found that the nickel (Ni), chromium $(\mathrm{Cr}), \mathrm{Cu}$, cadmium $(\mathrm{Cd})$, and mercury $(\mathrm{Hg})$ concentrations in most MSW compost products were below the legal restrictions (quality B in Table 4), except lead (Pb) in the compost of four MBT facilities and $\mathrm{Zn}$ in the compost of two MBT facilities, while all of the heavy metals satisfied the quality $C$ standard. However, a review by Farrell and Jones (2009) concluded that mechanically separated MSW compost exceeded the tolerable levels for most metals in comparison to UK standards (BSI-PAS 100:2011 in Table 4). It is meaningless to directly compare these conclusions, since the standards in Spain and the UK differ (see Table 4). However, it is generally acknowledged that heavy metals in mechanically separated MSW compost pose a greater challenge to agricultural applications. Similar conclusions can also be drawn from an analysis of 136 composting scenarios (see Fig. 3).

\subsubsection{Heavy metal control strategies}

4.3.2.1. Heavy metal process control. Elevated heavy metal concentrations pose potential risks to the environment. Process control is particularly important for mitigating these risks. For example, a series of process control measures can help reduce heavy metal levels in MSW compost products, including source separation, advanced mechanical segregation, and product refinement by removal of heavy metal-enriched fine particles via screening (Richard and Woodbury, 1992; Zennaro et al., 2005; Sharifi and Renella, 2015), of which source separation is generally regarded as the most effective and promising method for improving compost quality in terms of metal content (Richard and Woodbury, 1992; Veeken and Hamelers, 2002; Hargreaves et al., 2008). The metal (Pb, 
$\mathrm{Zn}, \mathrm{Cu}, \mathrm{Cd}, \mathrm{Cr}$, and $\mathrm{Ni}$ ) contents in source-separated and mechanically separated MSW compost shown in Fig. 3 clearly indicate the effectiveness of source-separated collection on metal content control (see supporting information for detailed data used in this figure). It should be noted that it is difficult to make accurate comparisons among these studies, as they are heterogeneous in both their design and presentation of results. For example, several studies presented ranges, while others presented medians or means. However, the concentrations of all six heavy metals were significantly lower in source-separated compost than in mechanically separated compost.

4.3.2.2. End-of-product control of heavy metals. In an effort to minimize the risks associated with heavy metals in soil, most countries employ their own government controls over commercial compost production, either as regulations or guidelines. Table 4 lists the maximum acceptable metal concentrations for compost in select countries. Of the various compost quality control documents used in the nine countries shown in Table 4, the content of the heavy metals $\mathrm{Cd}, \mathrm{Hg}$, and $\mathrm{Pb}$ in compost are regulated in all countries, although the actual permitted levels vary, while $\mathrm{Cu}, \mathrm{Cr}, \mathrm{Ni}$, and $\mathrm{Zn}$ are regulated in most countries, and arsenic, selenium, and molybdenum are only restricted in a few countries.

Smith (2009) reviewed the literature in an effort to assess the risk of heavy metals from MSW compost used for land application. The compost derived from all types of MSW, including sourceseparated waste, green waste, and MBT waste residues (i.e., organic fraction), contained higher heavy metal levels than the background level in soil, of which $\mathrm{Pb}$ and $\mathrm{Zn}$ had the highest levels in most cases. Therefore, applying MSW compost to soil increases the metal content of the application site, leading to increased uptake of labile elements (e.g., $\mathrm{Zn}$ and $\mathrm{Cu}$ ) by crops, which may subsequently pose risks to humans (Hargreaves et al., 2008). Even within the legal limits, heavy metals are predicted to accumulate in soils or plants following the long-term application of MSW compost, as shown in studies from the Netherlands and Spain (Veeken and Hamelers, 2002; Madrid et al., 2007).

Several researchers have argued that it is necessary to set more rigid allowable limits for MSW compost to minimize such risks, but rigid limitations also lead to a reduction in the MSW compost market. Instead, more practical measures should be employed to reduce metal levels in compost. One suggestion includes tightly controlling the quality of compost products, especially for agricultural applications. Quality-based compost classifications that consider heavy metal concentrations are strongly recommended from the perspectives of both waste material recycling and environmental risk control. For example, premium compost would be suitable for agricultural applications, second tier compost could be used in landscape and forest improvement projects, and third tier compost, with the poorest quality, would be suitable for soil remediation projects or disposal in landfills. In addition to quality-based compost classifications, sources of composting feedstock should be taken into account when considering compost applications. For example, it is highly recommended that compost-like materials derived from mixed MSW should not be used as true compost in agriculture applications.

\section{Conclusions}

The source separated collection and recycling of OFMSW are crucial processes for establishing sustainable waste management strategies. Composting, which has clear benefits from both ecological and economic perspectives, is an important process for the promotion of organic waste recycling. However, compared with readily recyclable materials such as paper and metal, recy- cling/composting of biodegradable MSW, especially food waste from households, has become a great challenge to further promoting waste recycling rates. Odor generation is the most challenging environmental factor for the sustainable management of composting plants. Of all the chemical compounds responsible for olfactory effects, ethylbenzene, terpenes, ammonia, amines, acetic acid, and hydrogen sulfide are frequently found to exceed the olfactory threshold, indicative of their dominant contributions to the olfactory effect. Although odor emissions can be decreased by process optimization, effective end-of-pipe control measures, such as biofiltration, are indispensable. Similar to odorous gases, bioaerosol generation is a concern in composting operations due to proven negative health effects. However, there is limited research concerning methods for controlling bioaerosol generation and dispersal. Mechanically separated MSW composting tends to produce lower-quality outputs (e.g., higher heavy metal contents) than source-separated MSW composting. Therefore, waste composting should be implemented in conjunction with source-separated collection to ensure the production of high-quality compost. In addition, quality-based compost classifications are strongly recommended from the perspective of waste material recycling and environmental risk control. Moreover, composting feedstock sources should be taken into account when considering applications; for example, more precautions should be taken when using mixed MSW-derived compost.

With the urgent need to establish high recycling rates in countries worldwide, source separation of waste will continue to be implemented in more countries and regions. By consequence, more high-quality raw materials will become available, which is prerequisite for producing high-quality compost products. From this perspective, composting will likely become an increasingly important component in waste treatment systems.

\section{Acknowledgements}

This work was supported by National Natural Science Foundation of China (Grant No. 51308564), and National Science Foundation Project of CQ CSTC (Grant No. CSTC2014jcyjA20015).

\section{Appendix A. Supplementary data}

Supplementary data associated with this article can be found, in the online version, at http://dx.doi.org/10.1016/j.resconrec.2017. 01.024 .

\section{References}

Association for Organics Recycling (AFOR), 2009. Market survey of the UK organics recycling industry - 2007/08. http://www.organics-recycling.org.uk/uploads/ article1769/WRAP_AFOR_Report_0708_-_FINAL_AFOR_3__cg.

pdf\#search='Market+survey+of+the+UK+organics+recycling+industry++ 2007\%2F08' (Accessed 09 March 2016).

Adhikari, B.K., Barrington, S., Martinez, J., King, S., 2008. Characterization of food waste and bulking agents for composting. Waste Manage. 28, 795-804.

Adhikari, B.K., Barrington, S., Martinez, J., King, S., 2009. Effectiveness of three bulking agents for food waste composting. Waste Manage. 29, 197-203.

Albrecht, A., Witzenberger, R., Bernzen, U., Jackel, U., 2007. Detection of air borne microbes in a composting facility by cultivation based and cultivationindependent methods. Ann. Agric. Environ. Med. 14, 81-85.

Alexis, M.T., James, R.M., 2009. Sustainable recycling of municipal solid waste in developing countries. Waste Manage. 29, 915-923.

Awasthi, M.K., Pandey, A.K., Bundela, P.S., Khan, J., 2015. Co-composting of organic fraction of municipal solid waste mixed with different bulking waste: characterization of physicochemical parameters and microbial enzymatic dynamic. Bioresour. Technol. 182, 200-207.

Bünger, J., Schappler-Scheele, B., Hilgers, R., Hallier, E., 2007. A 5-year follow-up study on respiratory disorders and lung function in workers exposed to organic dust from composting plants. Int. Arch. Occup. Environ. Health 80, 306-312.

Bell, B., Platt, B., 2014. Building Healthy Soils with Compost to Protect Watersheds. Institute for Local Self-Reliance, http://ilsr.org/wp-content/uploads/2013/05/ Compost-Builds-Healthy-Soils-ILSR-5-08-13-2. 
pdf\#search $=\% 27$ the + humus + materials + in + compost + functions + as $+a+$ glue + that +keeps+soil+particles+stuck+together+and+resilient+to+eroding+forces\%27 (Accessed 16 November 2016)

Bindra, N., Dubey, B., Dutta, A., 2015. Technological and life cycle assessment of organics processing odor control technologies. Sci. Total. Environ. 527-528, 401-412.

Bridgwater, E., Quested, T., 2012. Synthesis of Food Waste Compositional Data, http://www.wrap.org.uk/sites/files/wrap/hhfdw-synthesis-food-wastecomposition-data. pdf\#search=\%E2\%80\%98Synthesis+of+Food+Waste+Compositional + Data\%2C+WRAP+2012\%E2\%80\%99 (Accessed 29 November 2015)

Byeon, J.H., Park, C.W., Yoon, K.Y., Park, J.H., Hwang, J., 2008. Size distributions of total air borne particles and bioaerosols in a municipal composting facility. Bioresour. Technol. 99, 5150-5154.

Chen, J.Q., Liu, D.H., 2010. Heat value monitoring of Xiamen domestic waste and analysis of its influencing factors. Environ. Sanit. Eng. 18, 14-15 [in Chinese].

Chen, M., Xu, P., Zeng, G.M., Yang, C.P., Huang, D.L., Zhang, J.C., 2015. Bioremediation of soils contaminated with polycyclic aromatic hydrocarbons, petroleum, pesticides, chlorophenols and heavy metals by composting: applications, microbes and future research needs. Biotechnol. Adv. 33, 745-755.

Cheng, H.F., Hu, Y.N., 2010. Municipal solid waste (MSW) as a renewable source of energy: current and future practices in China. Bioresour. Technol. 101, 3816-3824.

Chung, Y.C., 2007. Evaluation of gas removal and bacterial community diversity in a biofilter developed to treat composting exhaust gases. J. Hazard. Mater. 144, $377-385$.

Department for Environment Food \& Rural Affairs (DEFRA), 2013. National compositional estimates for local authority collected waste and recycling in England, 2010/11. http://randd.defra.gov.uk/Default. aspx?Module=More\&Location=None\&ProjectID=18237 (Accessed 12 November 2016).

Department for Environment, Food \& Rural Affairs (DEFRA), 2015. Household recycling by material and region, England: April 1996 to March 2010 and Local authority collected waste from households from January 2010 to March 2015 England data. https://www.gov.uk/government/statistical-data-sets/env18local-authority-collected-waste-annual-results-tables (Accessed 29 November 2015).

Department for Environment, Food \& Rural Affairs, 2015. Digest of Waste and Resource Statistics, 2015. https://www.gov.uk/government/collections/digestof-waste-and-resource-statistics (Accessed 29 November 2015).

Devos, M., Patte, F., Rouault, J., Laffort, P., Van Gemert, L.J., 1990. Standardized Human Olfactory Thresholds. Oxford University Press, Oxford, UK.

Domingo, J.L., Nadal, M., 2009. Domestic waste composting facilities: a review of human health risks. Environ. Int. 35, 382-389.

Douwes, J., Thorne, P., Pearce, N., Heederik, D., 2003. Bioaerosol health effects and exposure assessment: progress and prospects. Ann. Occup. Hyg. 47, 187-200.

European Compost Network (ECN), 2014. European Quality Assurance Scheme for Compost and Digestate, http://www.compostnetwork.info (Accessed 11 November 2016).

Edwards, J., Othman, M., Burn, S., 2015. A review of policy drivers and barriers for the use of anaerobic digestion in Europe, the United States and Australia. Renew. Sustain. Energy Rev. 52, 815-828.

Eitzer, B.D., 1995. Emissions of volatile organic chemicals from municipal solid waste composting facilities. Environ. Sci. Technol. 29, 896-2902.

Eriksson, M., Strid, I., Hansson, P., 2015. Waste management carbon footprint of food waste management options in the waste hierarchy - a Swedish case study. J. Clean. Prod. 93, 115-125.

Eurostat, 2015. Municipal waste statistics. http://ec.europa.eu/eurostat/statisticsexplained/index.php/Municipal waste_statistics (Accessed 09 March 2016).

Farrell, M., Jones, D.L., 2009. Critical evaluation of municipal solid waste composting and potential compost markets. Bioresour. Technol. 100, 4301-4310

Fischer, G., Albrecht, A., Jäckel, U., Kämpfer, P., 2008. Analysis of airborne microorganisms, MVOC and odour in the surrounding of composting facilities and implications for future investigations. Int. J. Hyg. Environ. Health. 211, 132-142.

Fischer, C., Lehner, M., McKinnon, D.L., 2012. Overview of the Use of Landfill Taxes in Europe, http://scp.eionet.europa.eu/publications/WP2012_1/wp/WP2012_1 (Accessed 11 November 2016)

Food statistic of pocketbook, 2014. https://www.gov.uk/government/uploads system/uploads/attachment_data/file/423616/foodpocketbook-2014report23apr15.pdf\#search='Food+statistic+of+pocketbook+2014 (Accessed 29 November 2015).

Galera, M.M., Cho, E., Kim, Y., Farnazo, D., Park, S.J., Oh, Y.S., Park, J.K., Chung, W.J., 2008. Two-step pilot-scale biofilter system for the abatement of food waste composting emission. J. Environ. Sci. Health. Part A 43, 412-418.

Gu, B.X., Wang, H.K., Chen, Z., Jiang, S.Q., Zhu, W.M., Liu, M.M., Chen, Y.Q., Wu, Y., He, S., Cheng, R., Yang, J., Bi, J., 2015. Characterization, quantification and management of household solid waste: a case study in China. Resour. Conserv. Recycl. 98, 67-75.

Hargreaves, J.C., Adl, M.S., Warman, P.R., 2008. A review of the use of composted municipal solid waste in agriculture. Agric. Ecosyst. Environ. 123, 1-14

Hernández, J., Prado, Ó.J., Almarcha, M., Lafuente, J., Gabriel, D., 2010. Development and application of a hybrid inert/organic packing material for the biofiltration of composting off-gases mimics. J. Hazard. Mater. 178, 665-672.
Hernández, T., Garcia, E., García, C., 2015. A strategy for marginal semiarid degraded soil restoration: a sole addition of compost at a high rate. A five-year field experiment. Soil Biol. Biochem. 89, 61-71.

Hort, C., Gracy, S., Platel, V., Moynault, L., 2013. A comparative study of two composts as filter media for the removal of gaseous reduced sulfur compounds (RSCs) by biofiltration: application at industrial scale. Waste Manage. 33, $18-25$.

Huang, M.X., Liu, D., 2012. Characteristic and composition of municipal solid waste in sichuan province. Environ. Monit. China 28, 121-123 [in Chinese].

Huang, C.F., 2012. The Statistical Analysis of Characteristics of Municipal Solid Waste for Shenzhen. Huazhong University of Science \& Technology [in Chinese].

Jiang, T., Schuchardt, F., Li, G.X., Guo, R., Zhao, Y.Q., 2011. Effect of C/N ratio, aeration rate and moisture content on ammonia and greenhouse gas emission during the composting. J. Environ. Sci. 23 (10), 1754-1760

Jordāo, C.P., Nascentes, C.C., Cecon, P.R., Fontes, R.L.F., Pereira, J.L., 2006. Heavy metal availability in soil amended with composted urban solid wastes. Environ. Monit. Assess. 112, 309-326.

Komilis, D.P., Ham, R.K., 2006. Carbon dioxide and ammonia emissions during composting of mixed paper: yard waste and food waste. Waste Manage. 26, 62-70.

Komilis, D.P., Ham, R.K., Park, J.K., 2004. Emission of volatile organic compounds during composting of municipal solid wastes. Water Res. 38, 1707-1714.

Kupper, T., Bürge, D., Bachmann, H.J., Güsewell, S., Mayer, J., 2014. Heavy metals in source-separated compost and digestates. Waste Manage. 34, 867-874.

López, R., Cabeza, I.O., Giráldez, I., Díaz, M.J., 2011. Biofiltration of composting gases using different municipal solid waste-pruning residue composts: monitoring by using an electronic nose. Bioresour. Technol. 102, 7984-7993.

Laurent, A., Bakas, I., Lavreul, J., Bernstad, A., 2014. Review of LCA studies of solid waste management systems - part I: lessons learned and perspectives. Waste Manage. 34, 573-588.

Le Goff, O., Godon, J.J., Milferstedt, K., Bacheley, H., Steyer, J.P., Wéry, N., 2012. A new combination of microbial indicators for monitoring composting bioaerosols. Atmos. Environ. 61, 428-433.

Levis, J.W., Barlaz, M.A., Themelis, N.J., Ulloa, P., 2010. Assessment of the state of food waste treatment in the United States and Canada. Waste Manage. 30 1486-1494

Li, A.M., Li, D.F., Xu, X.J., 2008. A discussion on pretreatment to improve MSW incineration. Chin. J. Environ. Eng. 2, 830-834 [in Chinese]

Liu, C., Hotta, Y., Santo, A., Hengesbaugh, M., Watabe, A., Totoki, Y., Allen, D., Bengtsson, M., 2016. Food waste in Japan: trends, current practices and key challenges. J. Clean. Prod. 133, 557-564.

Ministry of Agriculture, Forestry and Fisheries of Japan (MAFF), 2013. Status survey on recycling of resources from wasted food. http://www.maff.go.jp/j/tokei/ kouhyou/zyunkan_sigen/index.html (Accessed 10 June 2015) [in Japanese].

Ministry of Agriculture, Forestry and Fisheries of Japan (MAFF), 2013. Food waste generation, reduction and recycling, 2008-2013. http://www.e-stat.go.jp/SG1/ estat/List.do bid $=000001050974 \&$ cycode $=0$ (Accessed 10 June 2015). [in Japanese].

Ministry of the Environment of Japan (MOEJ), 2015a. Waste treatment in Japan. http://www.env.go.jp/recycle/waste_tech/ippan/h25/index.html (Accessed 10 June 2015). [in Japanese].

Ministry of the Environment of Japan (MOEJ), 2015b. Investigation on generation of packaging waste. http://www.env.go.jp/recycle/yoki/c_2_research/research_ 11.html (Accessed 22 October 2016)[in Japanese].

Madrid, F., López, R., Cabrera, F., 2007. Metal accumulation in soil after application of municipal solid waste compost under intensive farming conditions. Agric. Ecosyst. Environ. 119, 249-256.

Mao, L.F., Tsai, C.J., Shen, D.H., Lin, T.F., Chen, W.K., Chen, M.L., 2006. Critical components of odors in evaluating the performance of food waste composting plants. Sci. Total. Environ. 370, 323-329

Maulini-Duran, C., Artola, A., Font, X., Sánchez, A., 2014a. Gaseous emissions in municipal wastes composting: effect of the bulking agent. Bioresour. Technol. 172, 260-268.

Maulini-Duran, C., Puyuelo, B., Artola, A., Font, X., Sánchez, A., Gea, T., 2014b. VOC emissions from the composting of the organic fraction of municipal solid waste using standard and advanced aeration strategies. J. Chem. Technol. Biotechnol. 89, 579-586

Montejo, C., Costa, C., Márquez, M.C., 2015. Influence of input material and operational performance on the physical and chemical properties of MSW compost. J. Environ. Manag. 162, 240-249.

National Bureau of Statistics of China, 2015. China Statistical Yearbook. Statistics Press, China, Beijing, China, pp. 2014 [in Chinese].

O'Connor, D.J., Daly, S.M., Sodeau, J.R., 2015. On-line monitoring of airborne bioaerosols released from a composting/green waste site. Waste Manage. 42 23-30.

Pagans, E., Barrena, R., Font, X., Sánchez, A., 2006. Ammonia emissions from the composting of different organic wastes: dependency on process temperature. Chemosphere 62, 1534-1542.

Pankhurst, L.J., Deacon, L.J., Liu, J., Drew, G.H., Hayes, E.T., Jackson, S., Longhurst, P.J. Longhurst, J.W.S., Pollard, S.J.T., Tyrrel, S.F., 2011. Spatial variations in airborne microorganism and endotoxin concentrations at green waste composting facilities. Int. J. Hyg. Environ. Health. 214, 376-383.

Pankhurst, L.J., Whitby, C., Pawlett, M., Larcombe, L.D., McKew, B., Deacon, L.J., Morgan, S.L., Villa, R., Drew, H.J., Tyrrel, S., Pollard, S.J.T., Coulo, F., 2012. 
Temporal and spatial changes in the microbial bioaerosol communities in green-waste composting. FEMS Microbiol. Ecol. 79 (1), 229-239.

Pearson, C., Littlewood, E., Douglas, P., Robertson, S., Gant, T.W., Hansell, A.L., 2015. Exposures and health outcomes in relation to bioaerosol emissions from composting facilities: a systematic review of occupational and community studies. J. Toxicol. Environ. Health B Crit Rev. 18 (1), 43-69.

Ping, S.K., Chi, S.P., 2009. Domestic waste management and recovery in Hong Kong J. Mater. Cycles Waste Manage. 11, 104-109.

Platt, B., Goldstein, N., Coker, C., Brown, S., 2014. Institute for Local Self-Reliance State of Composting in the U.S. - What, Why, Where \& How, https://ilsr.org/ state-of-composting/(Accessed 2 April 2016).

Puyuelo, B., Gea, T., Sánchez, A., 2010. A new control strategy for the composting process based on the oxygen uptake rate. Chem. Eng. J. 165, 161-169.

Qu, X.Y., Li, Z.S., Xie, X.Y., Sui, Y.M., Yang, L., Chen, Y., 2009. Survey of composition and generation rate of household wastes in Beijing. China. Waste Manage. 29, 2618-2624.

Richard, T.L., Woodbury, P.B., 1992. The impact of separation on heavy metal contaminants in municipal solid waste composts. Biomass. Bioenergy 3 , $195-211$

Ryu, H.W., Cho, K.S., Lee, T.H., 2011. Reduction of ammonia and volatile organic compounds from food waste-composting facilities using a novel anti-clogging biofilter system. Bioresour. Technol. 102, 4654-4660.

Scaglia, B., Orzi, V., Artola, A., Font, X., Davoli, E., Sánchez, A., Adani, F., 2011. Odours and volatile organic compounds emitted from municipal solid waste at different stage of decomposition and relationship with biological stability. Bioresour. Technol. 102, 4638-4645.

Schäfer, J., Klug, K., Van Kampen, V., Jäckel, U., 2013. Quantification of Saccharopolyspora rectivirgula in composting plants: assessment of the relevance of S, rectivirgula. Ann. Occup. Hyg. 57, 875-883.

Schlegelmilch, M., Streese, J., Biedermann, W., Herold, T., Stegmann, R., 2005 Odour control at biowaste composting facilities. Waste Manage. 25, 917-927.

Schlosser, O., Huyard, A., Rybacki, D., Quang, Z.D., 2012. Protection of the vehicle cab environment against bacteria, fungi and endotoxins in composting facilities. Waste Manage. 32, 1106-1115.

Seyring, N., Dollhofer, M., Weißenbacher, J., Herczeg, M., McKinnon, D., Bakas, I. 2015. Assessment of Separate Collection Schemes in the 28 Capitals of the EU (070201/ENV/2014/691401/SFRA/A2), http://ec.europa.eu/environment/ waste/studies/pdf/Separate\%20collection_Final\%20Report. pdf\#search=\%27separate+collection+of+waste+in+europe\%27 (Accessed 8 December 2016)

Shao, H.W., Xu, W.L., Kong, J.J., Patiguli, Ge C.H., Zhang, Y.S., Yu, J., Wang, W., 2009 Investigation and estimation of domestic waste in urumqi. Environ. Sanit. Eng. 17, 10-12 [in Chinese].

Shao, L.M., Zhang, C.Y., Wu, D., Lü, F., Li, T.S., He, P.J., 2014. Effects of bulking agent addition on odorous compounds emissions during composting of OFMSW. Waste Manag. 34, 1381-1390.

Sharifi, Z., Renella, G., 2015. Assessment of a particle size fractionation as a technology for reducing heavy metal, salinity and impurities from compost produced by municipal solid waste. Waste Manag. 38, 95-101.

Slater, R.A., Frederickson, J., 2001. Composting municipal waste in the UK: some lessons from Europe. Resour. Conserv. Recycl. 32, 359-374.

Smith, S.R., 2009. A critical review of the bioavailability and impacts of heavy metals in municipal solid waste composts compared to sewage sludge. Environ. Int. 35, 142-156.

Song, L.J., Chen, S.P., 2013. Status and development trend of waste composting biological treatment in China. Environ. Sanit. Eng. 21, 5-12.

Stagg, S., Bowry, A., Kelsey, A., Crook, B., 2010. Bioaerosol Emissions from Waste Composting and the Potential for Workers' Exposure. Health and Safety Executive, UK.

Staley, B.F., Xu, F., Cowie, S.J., Barlaz, M.A., Hater, G.R., 2006. Release of trace organic compounds during the decomposition of municipal solid waste components. Environ. Sci. Technol. 40, 5984-5991.

Swan, J.R.M., Kelsey, A., Crook, B., Gilbert, E.J., 2003. Occupational and Environmental Exposure to Bioaerosols from Composts and Potential Health Effects-a Critical Review of Published Data. Health and Safety Executive, UK.

Sykes, P., Jones, K., Wildsmith, J.D., 2007. Managing the potential public health risks from bioaerosol liberation at commercial composting sites in the UK: an analysis of the evidence base. Resour. Conserv. Recycl. 52 (2), 410-424.

Sykes, P., Morris, R.H.K., Allen, J.A., Wildsmith, J.D., Jones, K.P., 2011. Workers' exposure to dust, endotoxin and $\beta-(1-3)$ glucan at four large-scale composting facilities. Waste Manag. 31 (3), 423-430.

Taha, M.P.M., Drew, G.H., Longhurst, P.J., Smith, R., Pollard, S.J.T., 2006. Bioaerosol releases from compost facilities: evaluating passive and active source terms at a green waste facility for improved risk assessments. Atmos. Environ. 40 (6) 1159-1169.

Tai, J., Zhang, W.Q., Che, Y., Feng, D., 2011. Municipal solid waste source-separated collection in China: a comparative analysis. Waste Manage. 31, 1673-1682.

Takata, M., Fukushima, K., Kino-Kimata, N., Nagao, N., Niwa, C., Toda, T., 2012. The effects of recycling loops in food waste management in Japan: based on the environmental and economic evaluation of food recycling. Sci. Total Environ. 432, 309-317.

Tang, Y.T., Ma, X.Q., Lai, Z.Y., Zhou, D.X., Hai, L., Yong, C., 2012. $\mathrm{NO}_{\mathrm{x}}$ and $\mathrm{SO}_{2}$ emissions from municipal solid waste (MSW) combustion in $\mathrm{CO}_{2} / \mathrm{O}_{2}$ atmosphere. Energy 40, 300-306.

The State Council of the People's Republic of China, 2015. China's 13th Five-year Economic and Social Development Plan.
Thi, N.B.D., Kumar, G., Lin, C.Y., 2015. An overview of food waste management in developing countries: current status and future perspective. J. Environ. Manage. 157, 220-229.

Tsai, C.J., Chen, M.L., Ye, A.D., Chou, M.S., Shen, S.H., Mao, I.F., 2008. The relationship of odor concentration and the critical components mitted from food waste composting plants. Atmos. Environ. 42, 8246-8251.

UK Environment Agency, 2010. Position Statement: Composting and Potential Health Effects from Bioaerosols: Our Interim Guidance for Permit Applicants, http://www.norfolk.gov.uk/view/NCC115512 (Accessed 28 November 2015).

United States Environmental Protection Agency (USEPA), 2013. Advancing Sustainable Materials Management: 2013 Fact Sheet- Assessing Trends in Material Generation, Recycling and Disposal in the United State. June, 2015 https://ilsr.org/state-of-composting/(Accessed 10 June 2015).

United States Environmental Protection Agency (USEPA), 2015. DRAFT Inventory of U.S. Greenhouse Gas Emissions and Sinks: 1990-2014 (Chapter-7-Waste), http://www.epa.gov/climatechange/emissions/usinventoryreport.html (Accessed 12 February 2016).

Veeken, A., Hamelers, B., 2002. Sources of Cd, Cu, Pb and $\mathrm{Zn}$ in biowaste. Sci. Total. Environ. 300, 87-98.

Wéry, N., 2014. Bioaerosols from composting facilities-a review. Front. Cell. Infect. Microbiol, 4, 42-42.

Waite, S., Cox, P., Tudor, T., 2015. Strategies for local authorities to achieve the EU 2020 50\% recycling, reuse and composting target: a case study of England. Resour. Conserv. Recycl. 105, 18-28.

Walser, S.M., Gerstner, D.G., Brenner, B., Bünger, J., Eikmann, T., Janssen, B., Kolb, S. Kolk, A., Nowak, D., Raulf, M., Sagunski, H., Sedlmaier, N., Suchenwirth, R., Wiesmüller, G., Wollin, K.M., Tesseraux, I., Herr, C.E.W., 2015. Evaluation of exposure-response relationships for health effects of microbial bioaerosols - a systematic review. Int. J. Hyg. Environ. Health 218, 577-589.

Wei, Y.S., Fan, Y.B., Wang, M.J., Wang, J.S., 2000. Composting and compost application in China. Resour. Conserv. Recycl. 30, 277-300.

World Bank, 2005. Waste Management in China: Issues and Recommendations. http://siteresources.worldbank.org/INTEAPREGTOPURBDEV/Resources/ChinaWaste-Management1.

pdf\#search='The+Chinese+government+is+on+the+way+of+pursuing +a+sustainable+and+suitable+waste+management+strategy' (Accessed 8 December 2016).

Xiao, G., Ni, M.J., Chi, Y., Jin, B.S., Xiao, R., Zhong, Z.P., Huang, Y.J., 2009. Gasification characteristics of MSW and an ANN prediction model. Waste Manage. 29, 240-244.

Yang, F., Li, G.X., Yang, Q.Y., Luo, W.H., 2013. Effect of bulking agents on maturity and gaseous emissions during kitchen waste composting. Chemosphere 93, 1393-1399

Yao, J.L., Wand, H.Y., Yu, Y.J., Wang, Q., Wand, X.R., 2010. Pollution status and characteristics of heavy metals in sewage sludge from municipal wastewater treatment plants. Res. Environ. Sci. 23, 696-702 [in Chinese].

Yin, J., Xu, W.F., 2009. Ammonia biofiltration and community analysis of ammonia-oxidizing bacteria in biofilters. Bioresour. Technol. 100, 3869-3876.

Yuan, J., Yang, Q.Y., Zhang, Z.Y., Li, G.X., Luo, W.H., Zhang, D.F., 2015. Use of additive and pretreatment to control odors in municipal kitchen waste during aerobic composting. J. Environ. Sci. 37, 83-90.

Zennaro, M., Cristofori, F., Formigoni, D., Frignani, F., Pavoni, B., 2005. Heavy metal contamination in compost. A possible solution. Annal. Chim. 95, 247-256.

Zhang, J.S., Su, C.R., Xie, G., 2004. Treatment of MSW in Kunming. Yunnan Environ. Sci. 21, 3-5 [in Chinese]

Zhang, J., Yu, L.Z., He, P.J., Zhang, H., Shao, L.M., 2011. Effect of green wastes mixing on VSCs emission during MSW composting. China Environ. Sci. 31, 68-72.

Zhang, H.Y., Schuchardt, F., Li, G.X., Yang, J.B., Yang, Q.Y., 2013. Emission of volatile sulfur compounds during composting of municipal solid waste (MSW). Waste Manag. 33, 957-963.

Zhang, H.Y., Li, G.X., Gu, J., Wang, G.Q., Li, Y.Y., Zhang, D.F., 2016. Influence of aeration on volatile sulfur compounds (VSCs) and $\mathrm{NH}_{3}$ emissions during aerobic composting of kitchen waste. Waste Manag. 58, 369-375.

Zheljazkov, V., Warman, P.R., 2004. Source-separated municipal soil waste compost application to Swiss chard and basil. J. Environ. Qual. 33, 542-552.

Zhou, H., Meng A. h. Long, Y.Q., Li, Q.H., Zhang, Y.G., 2014. An overview of characteristics of municipal solid waste fuel in China: physical, chemical composition and heating value. Renew. Sustain. Energy Rev. 46, 107-122.

Zhou, H., Meng, A.H., Lang, Y.Q., Li, Q.H., Zhang, Y.G., 2015. An overview of characteristics of municipal solid waste fuel in China: physical, chemical composition and heating value. Renew. Sustain. Energy Rev. 46, 107-122.

Zhu, M.H., Fan, X.M., Rovetta, A., He, Q.C., Vicentini, F., Liu, B.K., Giusti, A., Yi, L., 2009. Municipal solid waste management in pudong new area, China. Waste Manage. 29, 1227-1233.

Zhuang, Y., Wu, S.W., Wang, Y.L., Wu, W.X., Chen, Y.X., 2008. Source separation of household waste: a case study in China. Waste Manage. 28, 2022-2030.

van Kampen, V., Deckert, A., Hoffmeyer, F., Taeger, D., Brinkmann, E., Brüning, T., Raulf-Heimsoth, M., Bünger, J., 2012. Symptoms, spirometry, and serum antibody concentrations among compost workers exposed to organic dust. J. Toxicol. Environ. Health. Part A 75, 492-500.

van Kampen, V., Sander, I., Liebers, V., Deckert, A., Neumann, H.D., Buxtrup, M., Willer, E., Felten, C., Jäckel, U., Klug, K., Brüning, T., Raulf, M., Bünger, J., 2014 Concentration of bioaerosols in composting plants using different quantification methods. Ann. Occup. Hyg. 58, 693-706. 